\title{
Bioethanol from corn stover - Global warming footprint of alternative biotechnologies
}

Zhao, Yan; Damgaard, Anders; Xu, Yingjie; Liu, Shan; Christensen, Thomas Højlund

Published in:

Applied Energy

Link to article, DOI:

10.1016/j.apenergy.2019.04.037

Publication date:

2019

Document Version

Peer reviewed version

Link back to DTU Orbit

Citation (APA):

Zhao, Y., Damgaard, A., Xu, Y., Liu, S., \& Christensen, T. H. (2019). Bioethanol from corn stover - Global warming footprint of alternative biotechnologies. Applied Energy, 247, 237-253.

https://doi.org/10.1016/j.apenergy.2019.04.037

\section{General rights}

Copyright and moral rights for the publications made accessible in the public portal are retained by the authors and/or other copyright owners and it is a condition of accessing publications that users recognise and abide by the legal requirements associated with these rights.

- Users may download and print one copy of any publication from the public portal for the purpose of private study or research.

- You may not further distribute the material or use it for any profit-making activity or commercial gain

- You may freely distribute the URL identifying the publication in the public portal

If you believe that this document breaches copyright please contact us providing details, and we will remove access to the work immediately and investigate your claim 


\title{
Bioethanol from corn stover - \\ Global warming footprint of alternative biotechnologies
}

\author{
Yan Zhao $^{\mathrm{a}}$, Anders Damgaard ${ }^{\mathrm{b}}$, Yingjie Xu ${ }^{\mathrm{a}}$, Shan Liu ${ }^{\mathrm{a}}$ and Thomas H. Christensen ${ }^{\mathrm{b},{ }^{*}}$ \\ ${ }^{a}$ School of Environment, Beijing Normal University, Beijing 100875, China \\ ${ }^{b}$ Department of Environmental Engineering, Technical University of Denmark, Kgs. \\ Lyngby 2800, Denmark
}

First author: Yan Zhao, yanzhao@bnu.edu.cn

Corresponding author: Thomas H. Christensen, thho@env.dtu.dk 


\begin{abstract}
Bioethanol from residual corn stover could contribute to lowering $\mathrm{CO}_{2}$ loads within the transport sector, if used as an amendment to gasoline. We modelled by life cycle assessment and Monte Carlo simulation seven different technological configurations for producing bioethanol from corn stover based on consistent mass flows and estimated ethanol production extracted from 141 datasets of reasonable quality. By parametrizing key processes and determining their statistical distribution based on actual data, we were able to estimate the Global Warming Potential (GWPs) for all the alternative technologies on a system level. Most of the individual cases showed a net saving in GWP when the savings obtained from recovering energy from anaerobic digestion of the liquid residues and incineration of the solid residues were included. The net savings could in some cases be as high as $900 \sim 1200 \mathrm{~kg} \mathrm{CO}$-eq/t dry corn stover solids. If the residues were not subject to energy recovery, the production of bioethanol and use in gasoline would be a net load to global warming in more than $50 \%$ of the technological configurations. The "best-practice", defined as the top $15 \%$ cumulative probability with respect to GWP, suggests that technologies based on steam explosion and ammonia-based pretreatment appear statistically the most promising and could contribute, with residue energy recovery, to GWP savings of $850-1050 \mathrm{~kg} \mathrm{CO}$-eq/t dry corn stover solids and produce in the range $178-216 \mathrm{~kg}$ of bioethanol. This paper provides insights into the key parameters for bioethanol production from corn stover and suggests areas for further research.
\end{abstract}

\title{
Keywords
}

Bioethanol; corn stover; life cycle assessment; global warming potential; probability distribution; uncertainty analysis

\footnotetext{
Abbreviations

PT, pretreatment; HL, hydrolysis; FT, fermentation; PS, pretreatment severity; SL, solid loading; TS, total solid; LCI, life cycle inventory; LCA, life cycle assessment; GWP, global warming potential.
} 


\section{Introduction}

In the quest to reduce the fossil component of transport fuel, amending bioethanol to gasoline (typically $5-15 \%$ ) has been introduced in many countries, for example in the USA, Brazil and India ${ }^{[1-3]}$. Producing ethanol through the bioconversion of lignocellulosic residues has proven feasible and is considered one of the most environmentally attractive approaches available, in particular with regard to savings in global warming impact within the transport sector ${ }^{[4,5]}$. However, the significant content of cellulosic compounds in the lignocellulosic feedstock is not converted easily to ethanol, and in recent years, much research and development has been reported on improving the efficiency of bioethanol production from lignocellulosic residues ${ }^{[6-8]}$. In particular, the bioconversion of corn stover has been a point of focus, because this residue is available in large quantities and at low cost. Concern over corn stover removal argued that some must be left on the field to sustain the humic content of the soil and maintain soil productivity ${ }^{[9]}$ and there may also be constraints in supply and its distribution ${ }^{[10,11]}$. In spite of this, corn stover has both economic and environmental potential for the production of bioethanol as an amendment to gasoline and thereby a substitute for fossil fuel ${ }^{[2,12]}$.

Given the complex lignocellulosic structure in corn stover, pretreatment is an important step in releasing cellulose from the restriction of hemicellulose and lignin, prior to hydrolysis, fermentation, and the final purification stages. In a recent review ${ }^{[13]}$ by the current authors, which included 474 published papers (see Section A1 in the Supplementary Information) reporting 561 datasets on the bioconversion of corn stover into bioethanol, we concluded that the majority of relevant publications focused on pretreatment processes, while very few of the published papers addressed the full technology covering pretreatment, hydrolysis, ethanol-fermentation, and distillation ${ }^{[13]}$. The review identified from the most consistent and complete datasets (141 out of 561 datasets), based on the pretreatment approach, eight different technological configurations for producing bioethanol from corn stover. The best technological configurations produced $19-22 \%$ ethanol (dry weight), while the technological configuration with the lowest efficiency produced only $11 \%$ ethanol ${ }^{[13]}$. Besides bioethanol production, it was observed in the review that all technological configurations produced large flows of solid and liquid residues, accounting for $55-75 \%$ of the carbon in the corn stover. The review also revealed within each technological configuration highly varying efficiencies within each process step, suggesting a potential for optimizing these individual process steps as well as overall ethanol production ${ }^{[13]}$. Considering the aim of reducing global warming impacts by substituting fossil fuel with bioethanol, the balancing of the ethanol production and the overall carbon footprint of the technology is crucial. The processing of residues, which is addressed rarely in the reported studies, may also strongly affect the overall global warming footprint of bioethanol technology, particularly if the residue is also used for energy recovery.

To understand and compare the environmental performance of bioethanol technologies and strategies, many studies have conducted life cycle assessment (LCA) on different systems with specific focuses, 
including cropping system ${ }^{[14]}$, feedstock supply ${ }^{[15]}$, soil sustainability ${ }^{[9,16]}$ and vehicle energy efficiency ${ }^{[17]}$. On a technological level, although some LCA studies have addressed the conversion of corn stover to ethanol including biotechnological, chemical and thermochemical processes ${ }^{[18-21]}$, the literature is not conclusive as to which technologies look most promising from a global warming perspective. This is primarily due to the research focus and limited statistical representativeness of the data included in different studies: Not all technological approaches to producing bioethanol have been included ${ }^{[18,22]}$, often only few cases or datasets have been used for each of the technologies involved [23, 24]; and in many cases the individual datasets were not covering the full technology from pretreatment to the ethanol product and data had been borrowed from other studies ${ }^{[25]}$. The many varying parameters observed in the bioconversion processes result in high levels of uncertainty regarding overall global warming potential. Incorporating quantification of uncertainty in the LCA and decision making can quantitatively address the risks of failure in technology selection and policy setting ${ }^{[26]}$.

Estimating the uncertainty of the global warming impact for a technology producing bioethanol is a prerequisite for comparison of technologies, and has been done in some relevant cases ${ }^{[27,28]}$. Spatari et al. evaluated key uncertainties of environmental impacts of two bioconversion technologies involving acid pretreatment and ammonia fibre explosion ${ }^{[29]}$. Recent work has also studied the uncertainty in greenhouse gas footprint of cellulosic biofuel production using ionic liquid pretreatment ${ }^{[30]}$. Monte Carlo simulation is an acknowledged methodology to investigate the uncertainty of the results and has been applied in assessing greenhouse gas emissions from biotechnologies involving polymer and ethanol production ${ }^{[31-33]}$. However, these studies mainly used uniform or triangular distributions ${ }^{[33]}$ due to the limited data for constructing statistical distributions, or assigned variations (e.g. $\pm 10 \%)^{[30]}$ for parameters in the absence of empirical data. While prior literatures focused on characterizing uncertainties related to specific inputs in the cellulosic ethanol supply chain ${ }^{[34,35]}$, many assuming specific technological configurations for bioethanol production, a general comparison of technologies for producing bioethanol based on consistent and transparent statistical data representing the full variation observed across all studies available within a technology is not possible to find in the existing literature.

Therefore, despite that many relevant papers already have been published, the current literature leaves a very scattered and incomplete picture on which technology for cellulosic bioethanol production is most successful in reducing greenhouse gas emissions. The knowledge gap is mainly attributed to the following reasons: 1) Diversity and complexity in relevant technological and scientific studies: the aims, methods and data forms of existing studies vary significantly making technological comparison difficult. 2) Variation in process parameters within and across the relevant technologies: the conclusions from existing LCA studies with few datasets are strongly dependent on the selection of the specific processes or parameters, and thus lack universality in technological comparison. 3) Lack of strong statistical and consistent data bases for technological comparison: consistent and transparent statistical data are not available for a general comparison of bioethanol technologies from the existing literature. 
To identify the most sustainable technologies for bioethanol production from corn stover from a global warming perspective, this work for the first time employed statistical data from 141 recently published but often incomplete - datasets of reasonable quality, to perform a fully transparent and systematic LCA, enhanced with estimates of the global uncertainties. Parametrization of all key processes within and across technologies allowed us to normalize the large amount of studies uniformly within and across all the technologies and to perform uncertainty propagation on a system level allowing for robust comparison of the alternative technologies with respect to global warming potential. This has to our knowledge not been done before and we believe this assessment can identify the most sustainable technological processes and identify where further research and development are needed. The solid statistical approach, probability information and novel findings of universal significance can thus highly contribute to the state-of-art knowledge of the bioethanol technologies based on corn stover.

\section{Approach and methods}

This section describes the eight technological configurations for producing bioethanol from corn stover and defines the characteristic technological parameters allowing us to model all flows through the full production configuration, from corn stover to marketable ethanol, including the treatment of solid and liquid residues. The life cycle assessment approach used to quantify the global warming impact is described as well, including a systematic assessment of the robustness of our results.

\subsection{Technological configurations}

A technological configuration refers to a combination of processes that addresses all steps needed in treating and converting corn stover to ethanol. Key steps in ethanol production are pretreatment, hydrolysis, fermentation, and purification, often as separate processes but sometimes combined. While a large range of pretreatment processes exists, hydrolysis, fermentation, and purification show much lower diversity. Within the individual practices, variations may appear, for example in solid loading, retention time, temperature, and chemicals used.

Pretreatment is a determining step in the bioconversion of corn stover to ethanol, because it strongly affects the availability of substrates for the enzymatic hydrolysis and determines the quantity and composition of side streams and residues not routed to the ethanol-producing reactor but treated by other means. Through data quality evaluation (see Zhao et al. ${ }^{[13]}$ ), 141 datasets with high completeness and consistency were selected from the reported 561 datasets in 474 published papers and classified into eight technological configurations determined by the pretreatment technology. The technological steps following pretreatment were all the same, although actual flows and parameter values vary, as observed in the literature ${ }^{[13]}$. All technological configurations enhance hydrolysis through enzyme addition, and the fermentation applies yeast or bacteria. We chose in the LCA model (inspired by the USA National 
Renewable Energy Laboratory ${ }^{[36]}$ ) for all eight technological configurations to route the liquid residues to anaerobic digestion and the solid residue to incineration. Both of these technologies have the potential to recover energy and thus to contribute to the global warming footprint of the technology. With this approach we also avoid the choice of residue handling actually affecting the overall results, except what is induced by the previous process steps, as they define the quantity and composition of the residues.

The eight biotechnological configurations are defined according to the pretreatment step described by Zhao et al. ${ }^{[13]}$; the parentheses show how many datasets were available within each technological configuration:

- S1-Acid (27 datasets from references ${ }^{[36-60]}$ ): Primarily dilute sulfuric acid pretreatment, occasionally hydrochloric acid and organic acid pretreatment. Pretreated corn stover is subjected to enzymatic hydrolysis and then fermentation after washing with water.

- S2-Alkaline (19 datasets from references ${ }^{[50,58,61-76]}$ ): Primarily sodium hydroxide pretreatment, occasionally calcium hydroxide and calcium carbonate pretreatment. Pretreated corn stover is subjected to enzymatic hydrolysis and then fermentation after washing with water.

- S3-Solvent-based (14 datasets from references [38, 42, 43, 45, 49, 77-85]): Ionic liquid (IL) and/or organic solvent (OS) pretreatment. Pretreated corn stover is subjected to enzymatic hydrolysis and then fermentation after solvent separation and washing with water or sometimes without washing.

- S4-Steam explosion (17 datasets from references ${ }^{[86-102]}$ ): Primarily steam explosion without a catalyst, and in one case acid is used as the catalyst. Pretreated corn stover is subjected to enzymatic hydrolysis and then fermentation after washing with water.

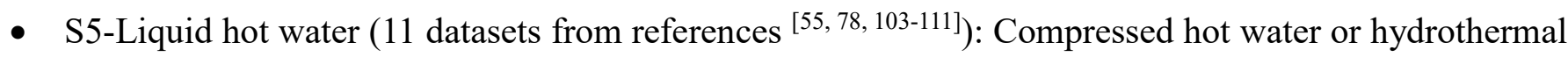
pretreatment without a catalyst. Pretreated corn stover is subjected to enzymatic hydrolysis and then fermentation after washing with water.

- S6-Ammonia-based (27 datasets from references [43, 45, 49, 58, 59, 84, 112-129]): Primarily ammonia fiber expansion, occasionally low-moisture anhydrous ammonia and ammonia recycle percolation pretreatment. Pretreated corn stover is subjected to enzymatic hydrolysis and then fermentation after ammonia removal or sometimes washing with water.

- S7-Fungi (11 datasets from references [73, 130-139]): Various fungal species used for pretreatment. Pretreated corn stover is subjected to enzymatic hydrolysis and then fermentation directly with two cases of washing with water.

- S8-Combi (15 datasets from references ${ }^{[117,118,140-152]}$ ): Various combinations of physical, chemical, and thermochemical pretreatment. Pretreated corn stover is subjected to enzymatic hydrolysis and then fermentation after washing with water.

\subsection{Key process parameters and data}


In order to compare the eight technological configurations we need consistent descriptions of the flows (mass, solids, key substrates, water) through the technological system and accounts of the energy that it takes to drive these flows through the system. This is done by modeling all the technological configurations with a set of parameters applying to all configurations, as we described in a previous paper [13]; see Table 1. In each technological process, the actual parameter values synthesized from the 141 datasets vary between technological configurations as well as within each technological configuration. Since details on electricity and heat consumption in the individual processes were reported rarely in the literature, data for energy consumption for fragmenting, mixing, heating, and distillation were calculated systematically as dependent parameters from the operational conditions, including mixing speed, solid loading, and temperature, as well as specific heat capacities of materials, as described in Sections A2.2 to A2.6 of Supplementary Information.

Table 1 Parameters used in modeling the eight process configurations for the bioconversion of corn stover into ethanol

\begin{tabular}{|c|c|c|c|c|}
\hline Classification & Parameter & Unit & Description & Unification basis \\
\hline $\begin{array}{l}\text { Raw material } \\
\text { composition }\end{array}$ & $\begin{array}{l}\text { GPP_RM } \\
\text { XPP_RM } \\
\text { LPP_RM } \\
\text { APP_RM } \\
\text { OPP_RM }\end{array}$ & $\begin{array}{l}\% \mathrm{TS} \\
\% \mathrm{TS} \\
\% \mathrm{TS} \\
\% \mathrm{TS} \\
\% \mathrm{TS}\end{array}$ & $\begin{array}{l}\text { Glucan proportion in raw materials } \\
\text { Xylan proportion in raw materials } \\
\text { Lignin proportion in raw materials } \\
\text { Ash proportion in raw materials } \\
\text { Other proportion in raw materials }\end{array}$ & $\begin{array}{l}\text { As reported, OOP_RM is } \\
\text { normalized from other } \\
\text { composition parameters }\end{array}$ \\
\hline Solid loading & $\begin{array}{l}\text { SL_PT } \\
\text { SL_PW } \\
\text { SL_HL } \\
\text { SL_FT }\end{array}$ & $\begin{array}{l}\% \text { wt } \\
\% \text { wt } \\
\% \text { wt } \\
\% w t\end{array}$ & $\begin{array}{l}\text { Total solid content in } \mathrm{PT}^{*} \\
\text { Total solid content in post-wash } \\
\text { Total solid content in HL* } \\
\text { Total solid content in FT* }\end{array}$ & $\begin{array}{l}\text { As reported or calculated } \\
\text { from water contents or } \\
\text { concentrations }\end{array}$ \\
\hline $\begin{array}{l}\text { Conversion } \\
\text { coefficient }\end{array}$ & $\begin{array}{l}\text { GEF_PT } \\
\text { GEF_HL } \\
\text { GEF_FT } \\
\text { XEF_PT } \\
\text { XEF_HL } \\
\text { XEF_FT } \\
\text { LEF_PT }\end{array}$ & $\begin{array}{l}\% \\
\% \\
\% \\
\% \\
\% \\
\% \\
\%\end{array}$ & $\begin{array}{l}\text { Glucan yield to solid phase in PT } \\
\text { Glucose yield to liquid phase in HL } \\
\text { Ethanol yield from glucose in FT } \\
\text { Xylan yield to solid phase in PT } \\
\text { Xylose yield to liquid phase in HL } \\
\text { Ethanol yield from xylose in FT } \\
\text { Lignin yield to solid phase in PT }\end{array}$ & $\begin{array}{l}\text { As reported or calculated } \\
\text { from substance } \\
\text { conversion in each } \\
\text { process and mass } \\
\text { balance, where necessary }\end{array}$ \\
\hline $\begin{array}{l}\text { Operational } \\
\text { condition }\end{array}$ & $\begin{array}{l}\text { T_PT } \\
\text { MS_PT } \\
\text { MS_HL } \\
\text { MS_FT } \\
\text { RT_PT } \\
\text { RT_HL } \\
\text { RT_FT } \\
\text { PS }\end{array}$ & $\begin{array}{l}{ }^{\circ} \mathrm{C} \\
\mathrm{rpm} \\
\mathrm{rpm} \\
\mathrm{rpm} \\
\mathrm{h} \\
\mathrm{h} \\
\mathrm{h}\end{array}$ & $\begin{array}{l}\text { Reaction temperature in PT } \\
\text { Mixing speed in PT } \\
\text { Mixing speed in HL } \\
\text { Mixing speed in FT } \\
\text { Reaction time in PT } \\
\text { Reaction time in HL } \\
\text { Reaction time in FT } \\
\text { Pretreatment severity }\end{array}$ & As reported \\
\hline $\begin{array}{l}\text { Material } \\
\text { consumption }\end{array}$ & $\begin{array}{l}\mathrm{CC} \text { PT } \\
\mathrm{CR} \text { PT } \\
\mathrm{BA} \mathrm{HL}\end{array}$ & $\begin{array}{l}\mathrm{kg} / \mathrm{kg} \\
\% \\
\mathrm{~kg} / \mathrm{kg}\end{array}$ & $\begin{array}{l}\text { Chemical consumption in PT } \\
\text { Chemical recovery ratio in PT } \\
\text { Enzyme consumption in HL }\end{array}$ & $\begin{array}{l}\text { As reported or calculated } \\
\text { from reported } \\
\text { information }\end{array}$ \\
\hline $\begin{array}{l}\text { Energy } \\
\text { consumption }\end{array}$ & 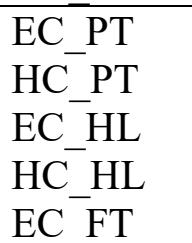 & $\begin{array}{l}\mathrm{kWh} / \mathrm{kg} \\
\mathrm{MJ} / \mathrm{kg} \\
\mathrm{kWh} / \mathrm{kg} \\
\mathrm{MJ} / \mathrm{kg} \\
\mathrm{kWh} / \mathrm{kg}\end{array}$ & $\begin{array}{l}\text { Electricity consumption in PT } \\
\text { Heat consumption in PT } \\
\text { Electricity consumption in HL } \\
\text { Heat consumption in HL } \\
\text { Electricity consumption in FT }\end{array}$ & $\begin{array}{l}\text { Calculated from } \\
\text { operational conditions } * *\end{array}$ \\
\hline
\end{tabular}




\section{HR PT $\quad \mathrm{MJ} / \mathrm{kg} \quad$ Heat recovery in PT}

* PT, HL, and FT stand for pretreatment, hydrolysis, and fermentation, respectively.

** Detailed calculation methods can be found in Supplementary Information.

\subsubsection{Literature datasets}

In the first part of this paper, we modeled the global warming impact of each dataset identified within the eight technological configurations, by applying the individual data for each parameter in Table 1. In total, we modeled 141 datasets, and the source data are available in the excel file of Supplementary Information. Data completeness was calculated for each individual dataset as the number of reported parameters relative to the total number of parameters (see Table 1). In consideration of the similarity of the processes within the same technological configuration, missing data needed for the flow modeling were substituted by median values of all the other existing data of the same parameter within the same technological configuration. The corn stover composition used was the one reported for the individual datasets.

\subsubsection{Monte Carlo simulations}

In the second part of this paper, we used Monte Carlo simulations to quantify the robustness of the modeling of seven of the eight technological configurations. For this purpose the data previously reported by the authors ${ }^{[13]}$, regarding the distribution of process parameters, were used. From a macroscopic and statistical point of view no important operational parameters were significantly correlated to the yields of bioethanol ${ }^{[13]}$, though this is normally true in microscopic and specific lab studies. This allowed us to treat all the parameters independently in the Monte Carlo simulation. Since $98 \%$ of the datasets identified in our previous work were from laboratory-scale studies applying batch reactors and only 6 pilot-scale datasets were among the 141 selected datasets ${ }^{[13]}$, scale was not assigned as a key parameter in our analysis due to lack of statistical significance. A specific probability distribution of each parameter was adopted on the basis of all the related datasets according to the approach described by Bisinella et al. ${ }^{[153]}$, including normal (ND), lognormal (LD), uniform (UD), and triangular (TD) distributions (details in Section A8.1 of Supplementary Information). These specific distributions were applicable to most of the parameter distributions and implemented in the Monte Carlo method in the EASETECH LCA model ${ }^{[154]}$ (see Section 2.5). The cumulative distribution of extracted data and fitting curves is shown in Section A8.1 of Supplementary Information. A Pearson's $\chi^{2}$ test was applied to test the goodness of fit of the distributions by means of the statistical software Minitab 17.1. Specifically, the probability distributions of parameters describing the pretreatment and hydrolysis processes were estimated for each technological configuration, while the probability distribution of parameters describing fermentation was estimated across all technological configurations, since fermentation showed no generic differences across the technological configurations. 
Technological configuration S8, which is a mix of different technologies using multistep processes with different characteristic parameters, did not provide data useful for estimating probability distributions and thus could not be subject to Monte Carlo simulation.

The corn stover composition used was the same for all seven technological configurations and defined as the average of 133 datasets containing information about the corn stover composition. The average corn stover composition in terms of TS was: Glucan $36.2 \% \pm 3.2 \%$, xylan $22.7 \% \pm 4.2 \%$, lignin $18.5 \% \pm 3.7 \%$, ash $5.0 \% \pm 2.7 \%$, and others $17.6 \% \pm 7.9 \%$. Chemical properties and the basis of composition calculation can be found in Section A9.1 of Supplementary Information.

\subsection{Defining the model system}

Our aim was to assess the global warming aspects of the eight identified different technological configurations for producing ethanol from corn stover while realizing that residues and side streams could also contribute significantly to the overall $\mathrm{CO}_{2}$ account of a technology. Thus, the functional unit of the assessment was defined as the "biorefinery of $1 \mathrm{t}$ (tonne, $1000 \mathrm{~kg}$ dry matter) of corn stover, with bioethanol as the major product". We assumed that the corn stover would be available and have no environmental rucksack in terms of global warming, as it is a waste material with no current use. We did not include any alternative use of the corn stover, soil carbon loss or indirect land use changes due to the use of the corn stover, but if known and the $\mathrm{CO}_{2}$ account is quantitative, then it is possible to combine this with the results presented in this paper.

The system boundary includes the collection, transportation, and mechanical preparation of the corn stover, all the major processes of bioethanol production, including use of water, chemicals, enzymes, and energy (Fig. 1), the treatment of solid and liquid residues, including water, heat, and power recovery from incineration and anaerobic digestion, as well as the downstream use of the recovered ethanol. Given that different technologies produce different amounts of bioethanol from the same amount of corn stover, we applied system expansion following key LCA principles, meaning that we subtracted the alternative products that are avoided when energy and materials are produced ${ }^{[155]}$. For comparison, net impacts of the technological alternatives were calculated by subtracting the impacts of gasoline production and combustion, as well as the impacts of any other products and energy produced. We assume that bioethanol substitutes for gasoline according to energy content, as specified in Section A3.2 of Supplementary Information. All impacts related to facility construction were excluded due to lack of information. The scenarios modeled are identical to the technological configurations presented earlier with the addition of upstream processes, liquid and solid residue handling, and downstream processes. 


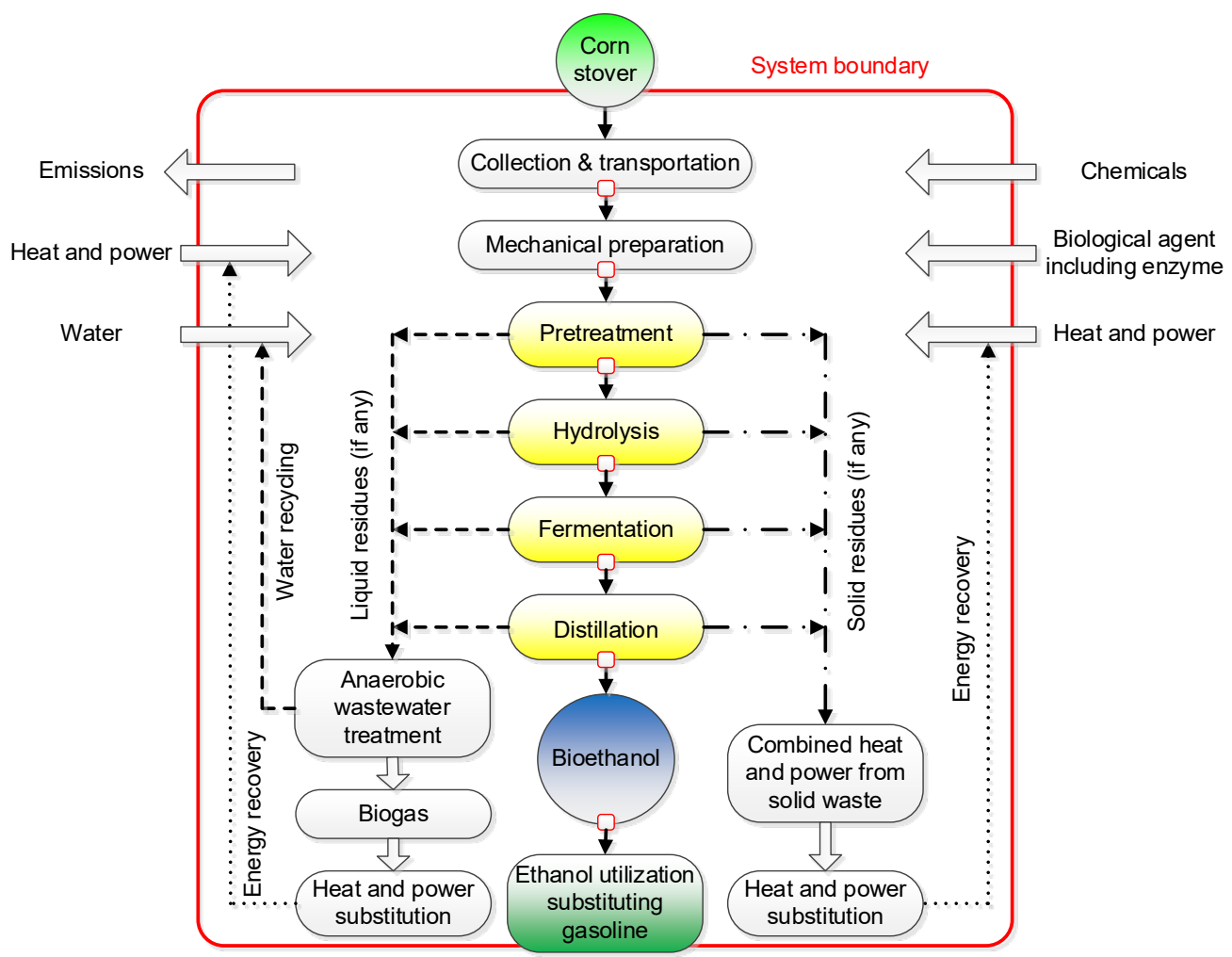

Fig. 1 System boundary for the biorefinery of corn stover to produce bioethanol.

To complete the necessary information for the LCAs, which were rarely reported in the literature, some of the processes were defined commonly for all configurations as listed below, while the other settings, including fuel substitution and enzyme consumption, can be found in Sections A3.2 and A4 of Supplementary Information.

- Fuel consumption in collection and transportation was set at $0.006 \mathrm{~L}$ diesel $/ \mathrm{kg}$ (TS) corn stover (see Section A3.1 in Supplementary Information); emissions from fuel combustion in collection and transportation were conservatively estimated according to the Euro 3 European Emission Standard.

- Electricity for mechanical preparation was set at $0.14 \mathrm{kWh} / \mathrm{kg}$ (TS) corn stover (see Section A2.1 in Supplementary Information).

- In the anaerobic digestion of liquid residues, the recovery efficiencies for heat and electricity were set at $46 \%$ and $39 \%$ of energy content of the produced biogas, respectively, and a biogas loss of $1 \%$ was assumed (see Section A5.1 in Supplementary Information).

- In the incineration of solid residues, the recovery efficiencies for heat and electricity were set at $75.7 \%$ and $18.4 \%$, respectively, on the basis of lower heating values of the solid residue (see Section A5.2 in Supplementary Information).

\subsection{Modeling tool and databases}

Flow modeling and life cycle assessment modeling with respect to climate change were done with EASETECH, a specialized LCA model developed according to ISO 14040 standards ${ }^{[156]}$ and allowing for 
process modeling and statistical assessment ${ }^{[154]}$. The LCA was done as an attributional LCA with system expansion.

The impact on global warming potential (GWP, also known as the climate change or $\mathrm{CO}_{2}$ footprint) is expressed in $\mathrm{CO}_{2}$-equivalent (eq) for all the relevant greenhouse gases, such as $\mathrm{CO}_{2}, \mathrm{CH}_{4}, \mathrm{~N}_{2} \mathrm{O}$, and CFCs, according to the IPCC 2013 method for climate change in 100 years' time ${ }^{[157]}$. Typically, we consider $\mathrm{CO}_{2}$ from corn stover as neutral $\left(0 \mathrm{~kg} \mathrm{CO}-\mathrm{eq} / \mathrm{kg}\right.$ biogenic $\left.\mathrm{CO}_{2}\right)$, while emitted $\mathrm{CO}_{2}$ from fossil fuels is ascribed a value of $1 \mathrm{~kg} \mathrm{CO}$-eq/ $/ \mathrm{kg}$ fossil $\mathrm{CO}_{2}$ and avoided fossil $\mathrm{CO}_{2}$ a value of $-1 \mathrm{~kg} \mathrm{CO}$-eq/ $\mathrm{kg} \mathrm{CO}$; methane emitted (as loss during the anaerobic digestion) is ascribed a value of $28.5 \mathrm{~kg} \mathrm{CO}$-eq $/ \mathrm{kg} \mathrm{CO}$.

The life cycle inventory (LCI) data for external processes, including chemicals, heat, electricity, and fuel production, were selected from Ecoinvent (allocation at the point of substitution) ${ }^{[158]}$, which has been acknowledged as an authoritative, consistent, and transparent LCI database. Global datasets were used where possible, since the study does not apply to any specific region. LCI data for one external process

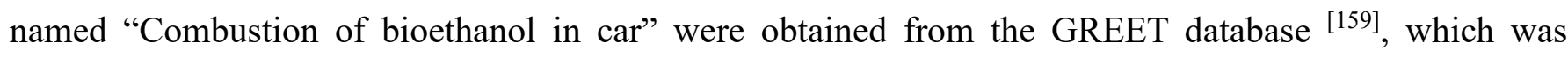
developed to evaluate the energy and emission impacts of new transportation fuels. In particular, the GWP of the substituted gasoline was $0.086 \mathrm{~kg} \mathrm{CO}$-eq/MJ according to the selected external process from Ecoinvent. The selected datasets are specified in Sections A6.1 and A6.2 of Supplementary Information. These datasets are identical for all the scenarios where used, including the use of heat and electricity. The exception is the datasets for which uncertainty analysis was carried out as presented in Section 3.5.

\subsection{Robustness analysis with statistical and probability approaches}

We assessed the robustness of the modeling results through uncertainty propagation (Monte Carlo), discernibility analysis, global sensitivity analysis, and scenario variation.

Uncertainty describes the overall variation of the result for each scenario, subject to the uncertainty of the parameters, and is obtained by systematically propagating the uncertainties of input parameters ${ }^{[26]}$. A Monte Carlo method is implemented in EASETECH to randomly sample values within each parameter distribution, in order to calculate the results of each scenario, here based on 10,000 samplings. The obtained results were used further to calculate for each scenario probability properties such as expectation value and mode, as well as to construct a frequency histogram and to compute a probability distribution within a $95 \%$ confidence level.

Discernibility focuses on the difference between two scenarios and expresses statistically how frequently one scenario is better than another when both scenarios are subject simultaneously to the same variations in common parameters ${ }^{[153]}$. The discernibility analysis is performed as part of the Monte Carlo simulation. 
Sensitivity describes how the results of a scenario vary as a consequence of a change in specific input parameters, and it is expressed via the sensitivity ratio (SR) calculated for each parameter in each scenario, as shown in $\mathrm{Eq}(1)^{[153]}$.

$$
S R_{i}=\frac{\frac{\Delta \text { result }}{\text { initial result }}}{\left(\frac{\Delta \text { parameter }}{\text { initial parameter }}\right)_{i}}
$$

where $i=1,2, \cdots, \mathrm{n}$ are tested parameters in the model (Table 1, Section 2.2). To perform the sensitivity analysis for each process configuration, the expectation values calculated from the distribution of each parameter were used as the basic values of the tested parameters. During the analysis, one parameter individually was increased and decreased by $1 \%$, in order to stay within a pseudo-linear range while keeping all the other parameters fixed at their basic values.

The global sensitivity analysis (also known as global importance analysis), which includes an analysis of the fundamental connections between the sensitivity and the uncertainty of individual parameters, was applied to present the contribution of each independent parameter to the variance of results, as described in the Section A10.2 of Supplementary Information.

Scenario variation describes how the results of a scenario vary subject to changes in boundary conditions or imports/exports over the boundary, for example if the energy used or substituted is of a different kind than first assumed. We maintained the assumption that ethanol substitutes for gasoline based on energy content, but we also varied the kind of electricity and heat used as well as the kind of electricity and heat substituted by the same sources of energy generated by anaerobic digestion and incineration.

\section{Results and discussion}

Based on the extracted datasets, five levels of assessment were performed to reveal and compare the performance of different process configurations for biorefinery with bioethanol production, i.e. the casespecific global warming potentials (GWPs) of the configurations, the distribution and uncertainty of the GWP, the global sensitivity of the key parameters, the "best-practice" analysis of the configurations, and scenario variations with different energy mixes. The results provide a comprehensive understanding of a state-of-art biorefinery producing bioethanol, from the perspective of an LCA.

\subsection{Global warming potentials of eight technological configurations}

The GWPs calculated per tonne of corn stover solids are shown for each of the 141 datasets in Figure 2, grouped within the eight technological configurations (reference numbers shown at the bottom of each figure accord with those in the reference list). Figure 2 shows the loads and savings according to the main contributions for each dataset as well as the data completeness of each dataset. As mentioned earlier, missing data of the individual datasets were supplemented with median values of all the other existing data of the same parameter within the same technological configuration. The figures are organized in ascending 
net GWP order; the more negative values, the more savings are obtained and the better the technology is with respect to global warming.

Figure 2 illustrates clearly that large variations are found within each of the technological configurations, within each of which a range of $1000 \mathrm{~kg} \mathrm{CO}$-eq/t TS can be found, suggesting that not all reported datasets represent the successful implementation of the technology, although ethanol was indeed produced. Some of the extreme cases are explained in Section A7.1 of Supplementary Information. Most of the technological configurations showed net savings (negative values) and thus contributed to savings in global warming impact terms. The loads to global warming were due mainly to the energy and chemicals used in pretreatment and the energy and enzymes used in hydrolysis. The significant contribution of enzyme to GWPs has been confirmed by special studies on industrial enzyme production ${ }^{[160]}$ as well as enzyme consumption in bioethanol production ${ }^{[161,162]}$. The specific contributions of input materials and energy are shown in Figure A3, Section A7.2 of Supplementary Information. The processes of collection and transport, mechanical preparation, fermentation, and disposal of residues after energy recovery showed only insignificant contributions to GWP. Additionally, GWP caused by water consumption was marginal, due to the low GWP of the water supply and the fact that we assumed a high level of water recycling, although hardly any datasets specifically addressed this aspect. The savings in GWP from substituting gasoline with bioethanol were significant but often of the same size as the GWP load from producing the bioethanol in the first instance. However, efficient energy recovery from incinerating the solid residues, and the efficient utilization of the gas generated by anaerobically digesting liquid residues, generated additional savings in GWP. Without ensuring efficient energy recovery from handling the residues, more than half of all the datasets reported added a net load to global warming and as such did not contribute to reducing the global impact from transport fuel, even though the produced bioethanol would substitute for fossil-based gasoline. Many datasets showed that the savings in global warming from residue energy recovery were of the same size as those obtained from substituting fossil fuel (in this case gasoline) with bioethanol. The electricity credits were also reported in other studies with different contributions to GWP savings ${ }^{[27,33]}$. It is worth noting that only $15-25 \%$ of the carbon in the corn stover ends up in the ethanol, and this contributes half of the savings measured as $\mathrm{CO}_{2}$-equivalents. Further details on the relative contributions, depending on the technological configurations, are given in Section A7.2 of Supplementary Information. 


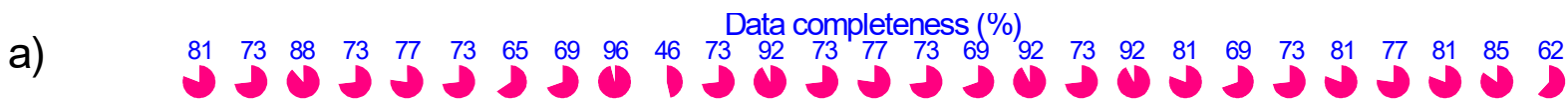

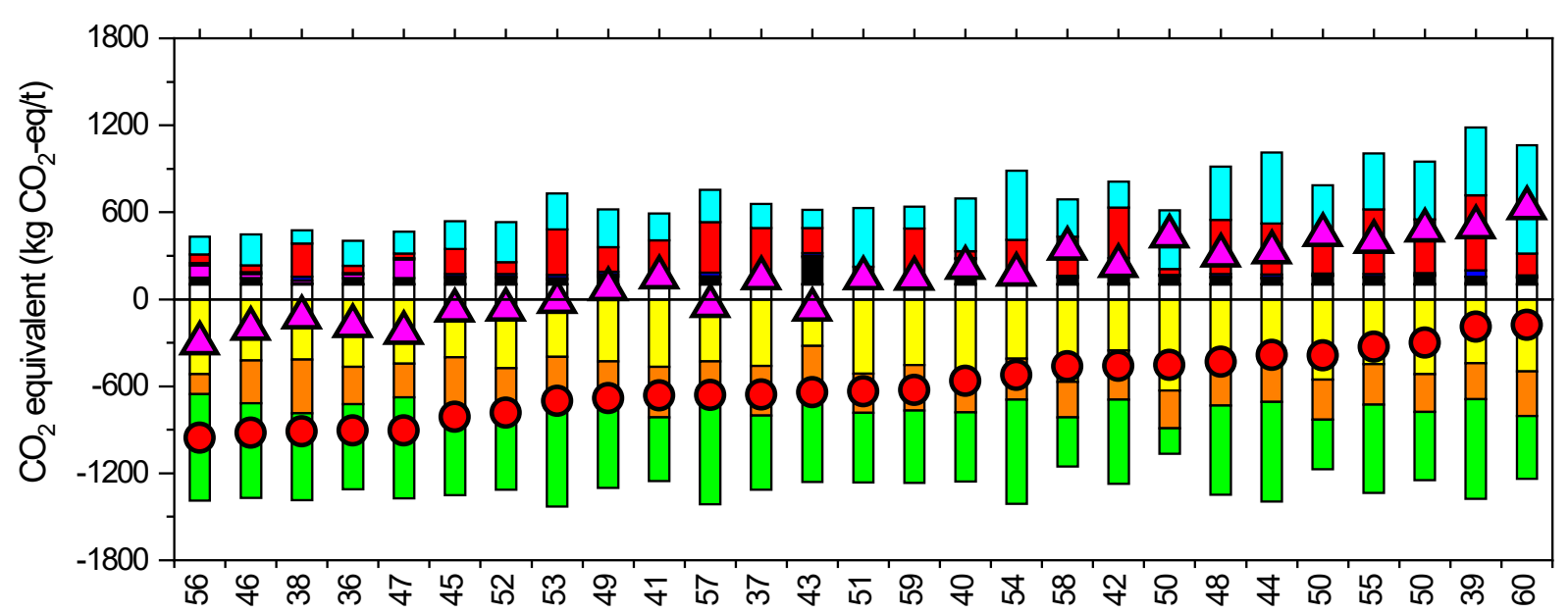
Ref. No.

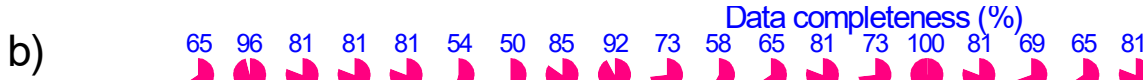

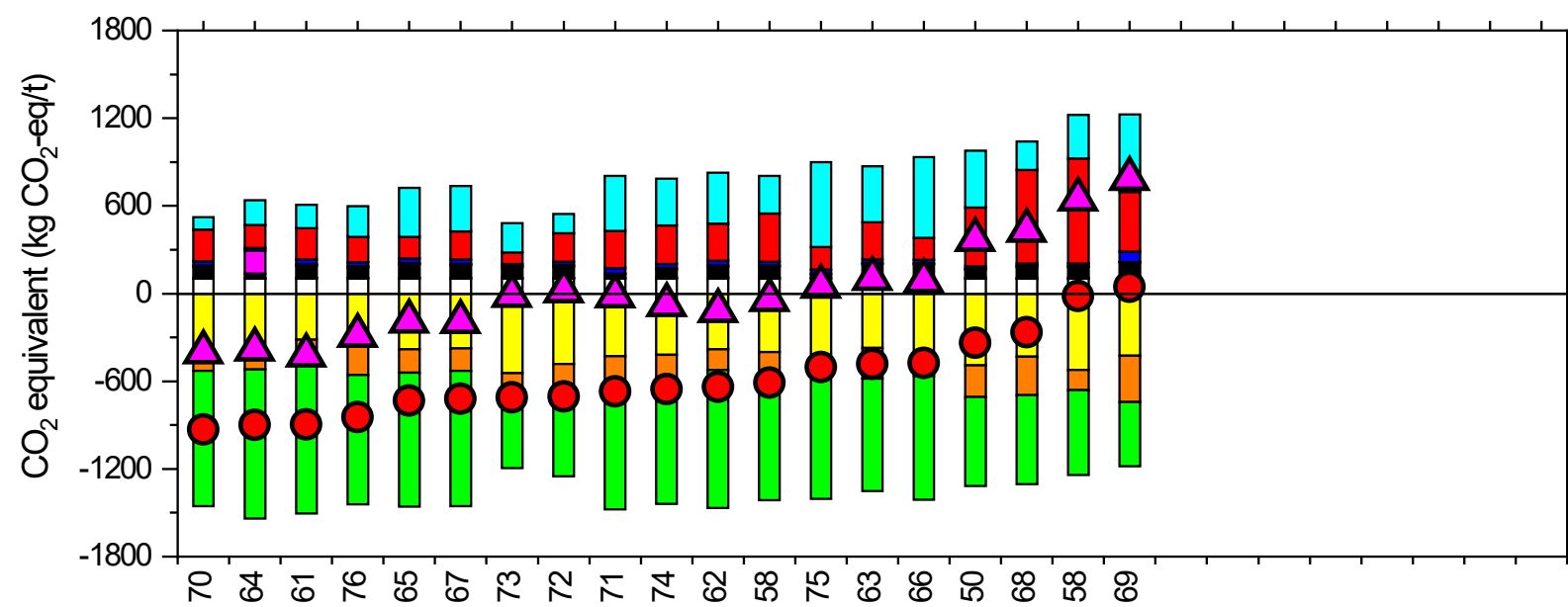
Ref. No.

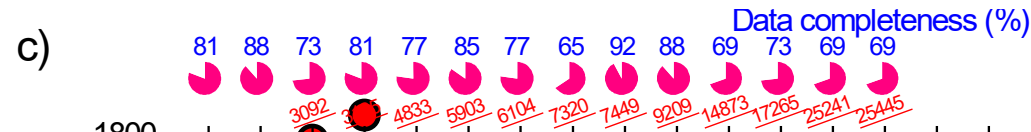

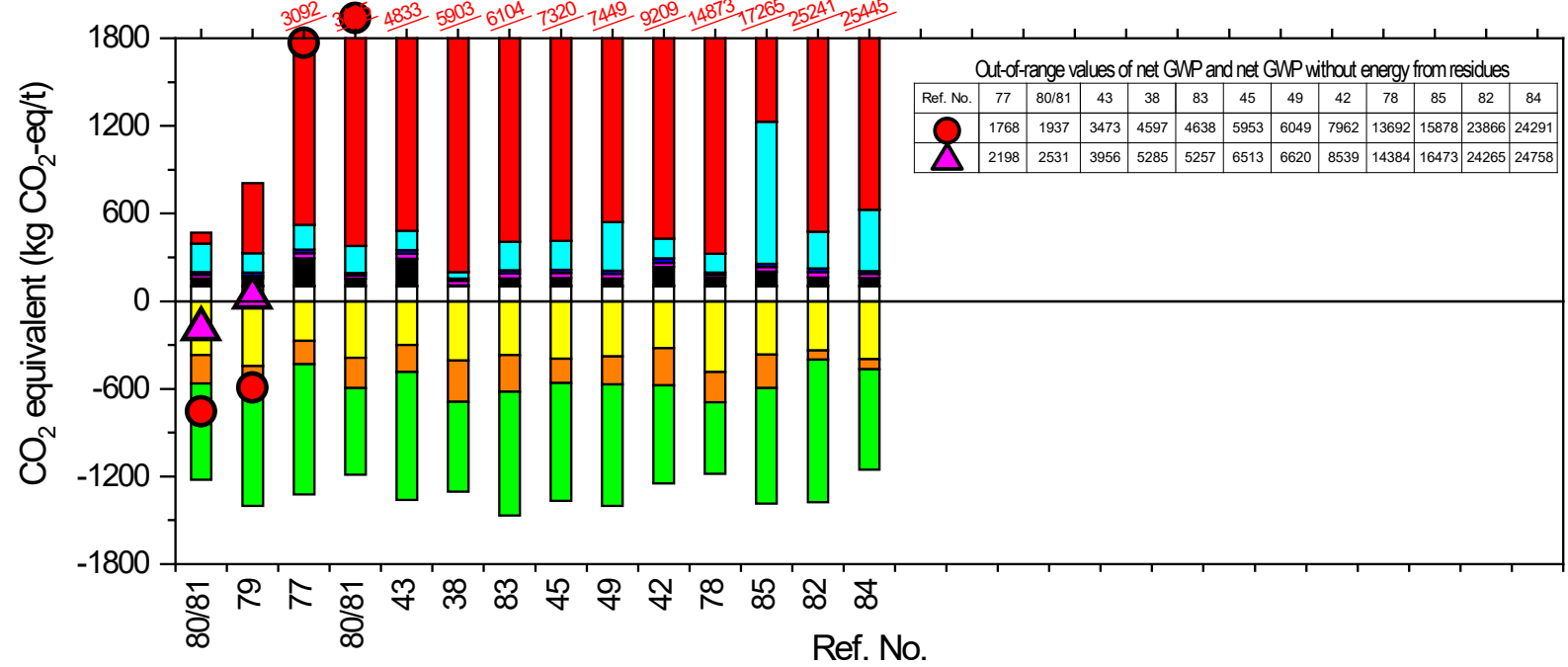




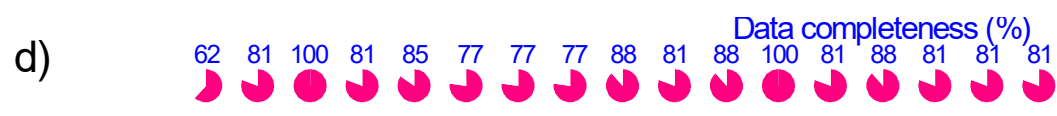

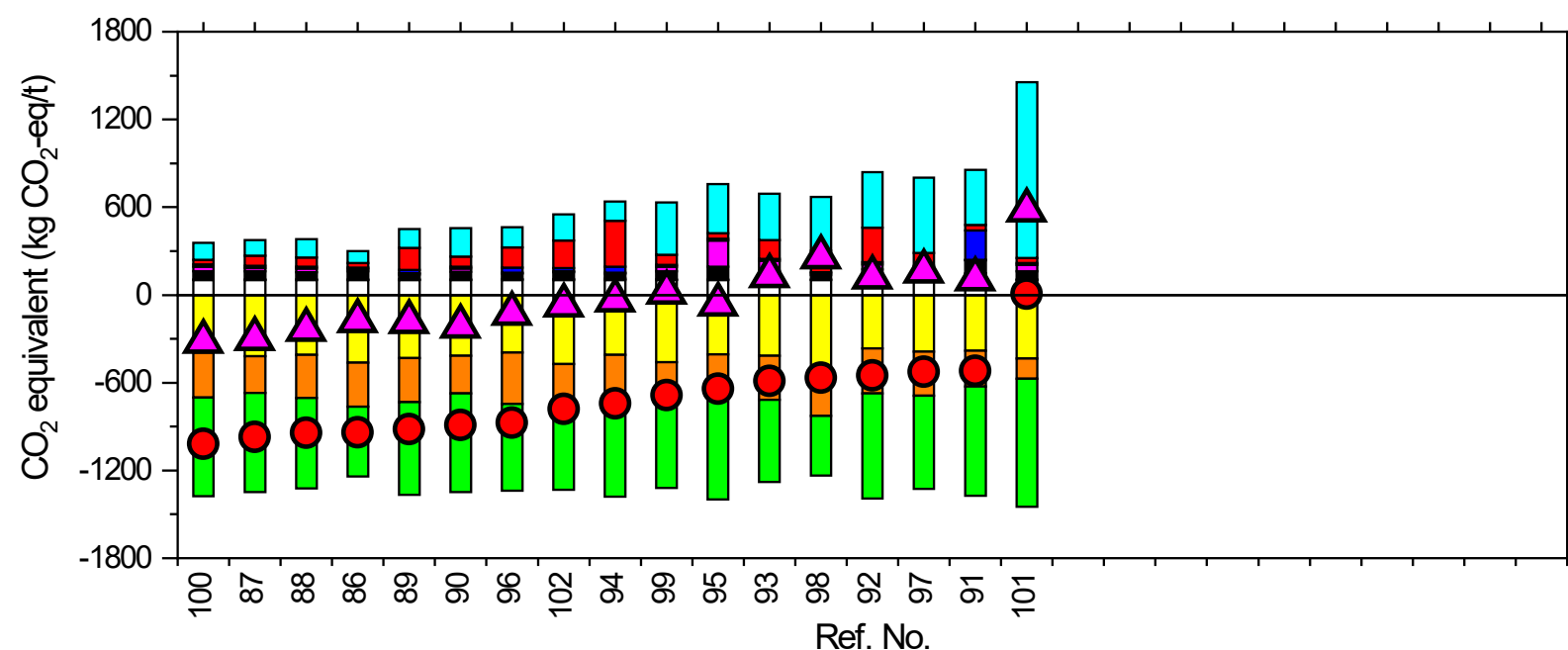

e) $\quad \begin{array}{lllllllllll}69 & 88 & 88 & 69 & 77 & 73 & 69 & 81 & 88 & 81 & 69\end{array}$

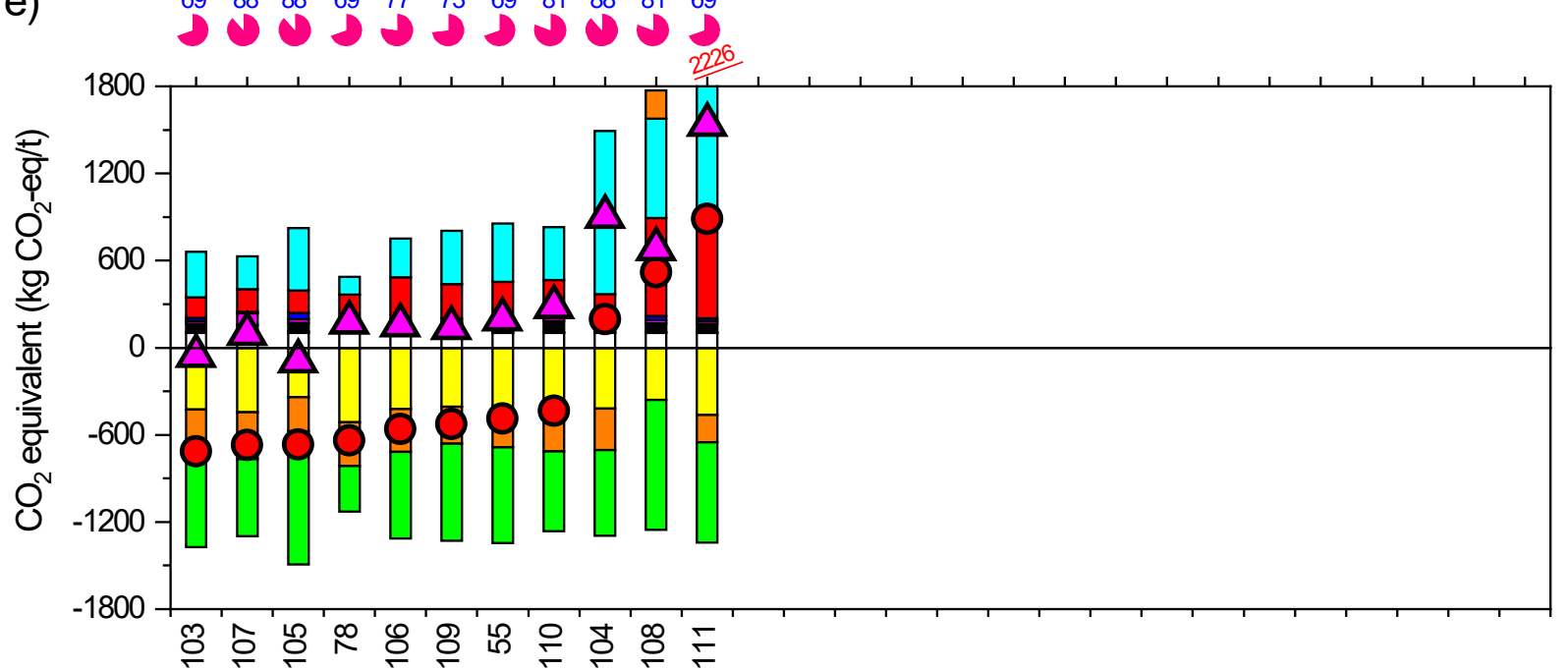

Ref. No.

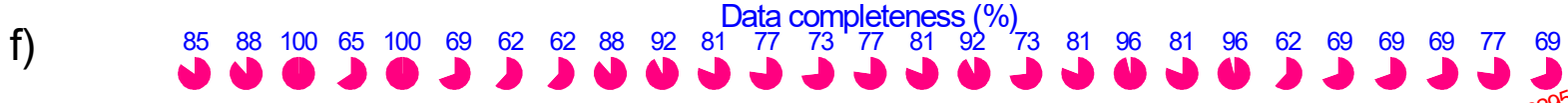

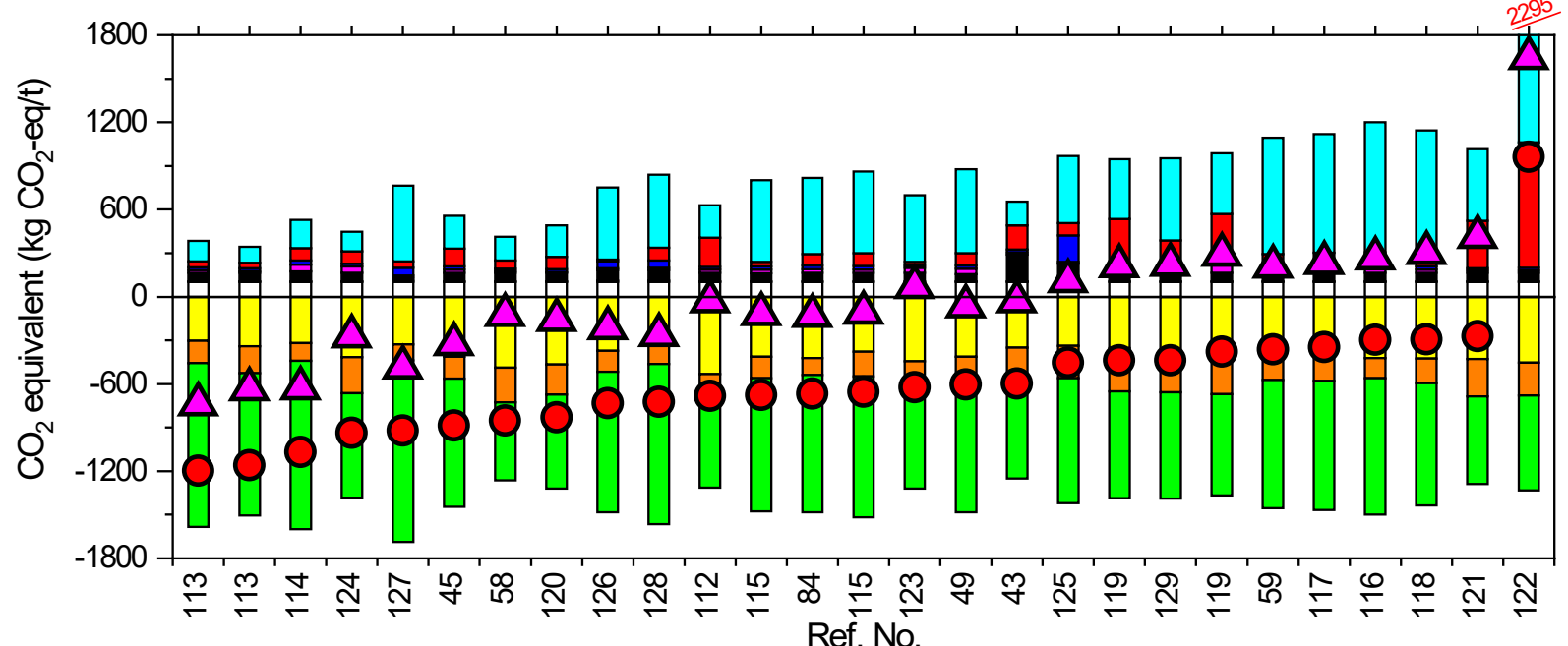
Ref. No. 


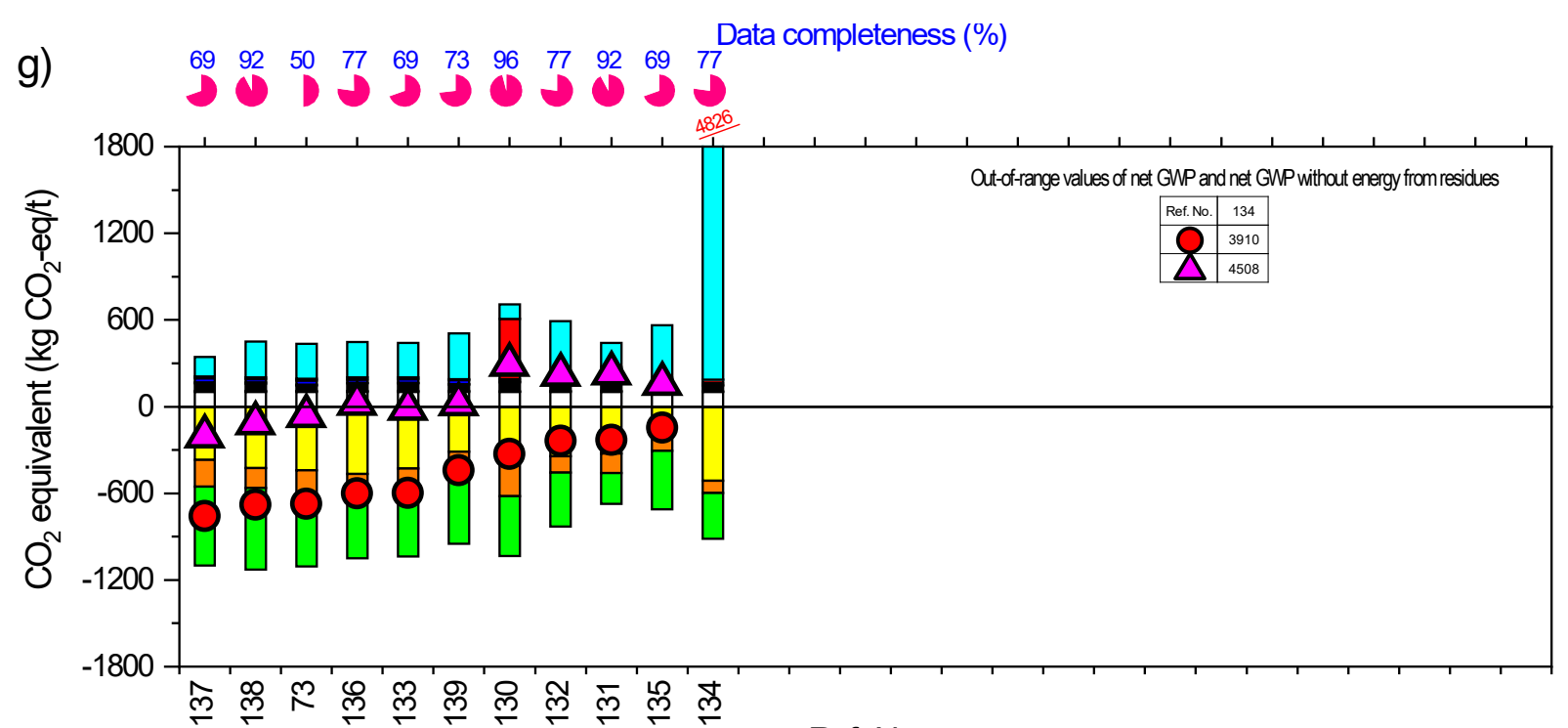

Ref. No.

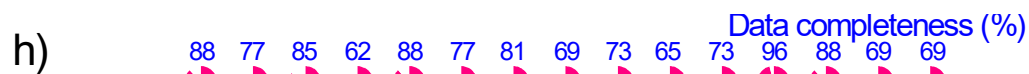

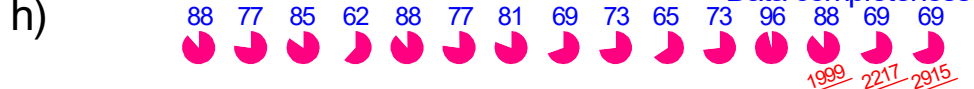

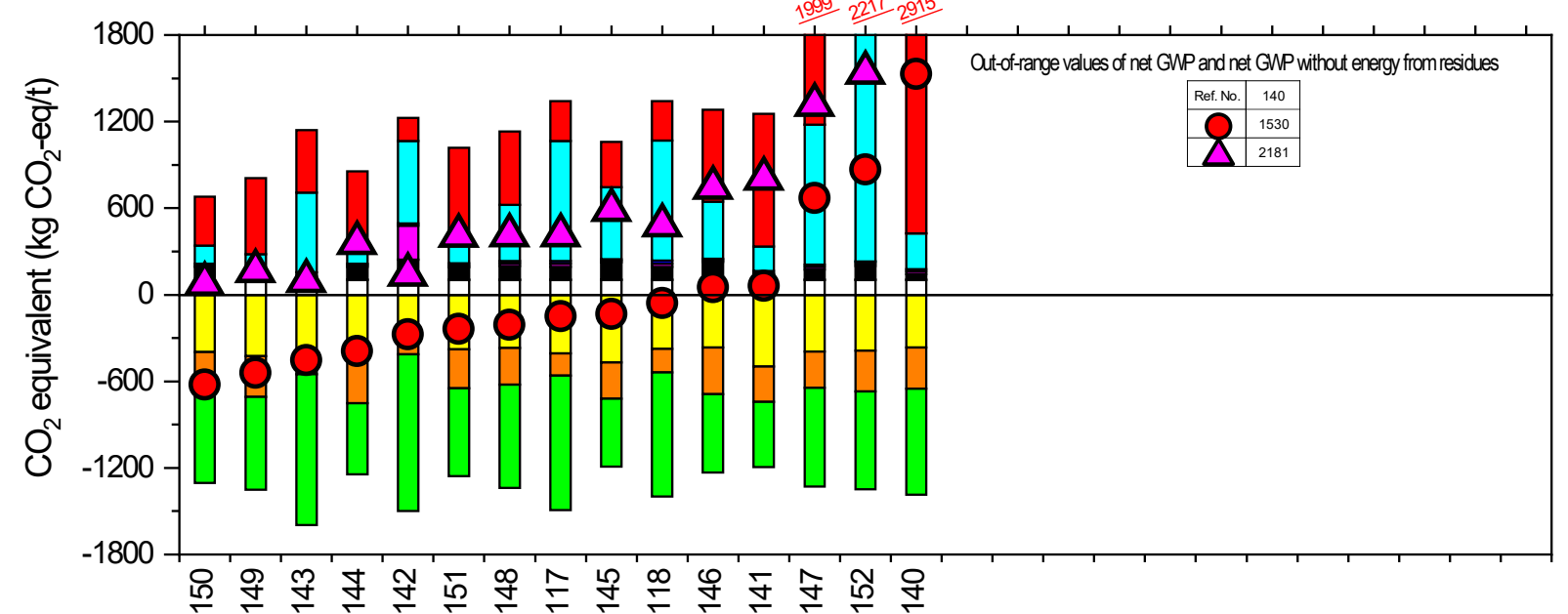

Ref. No.

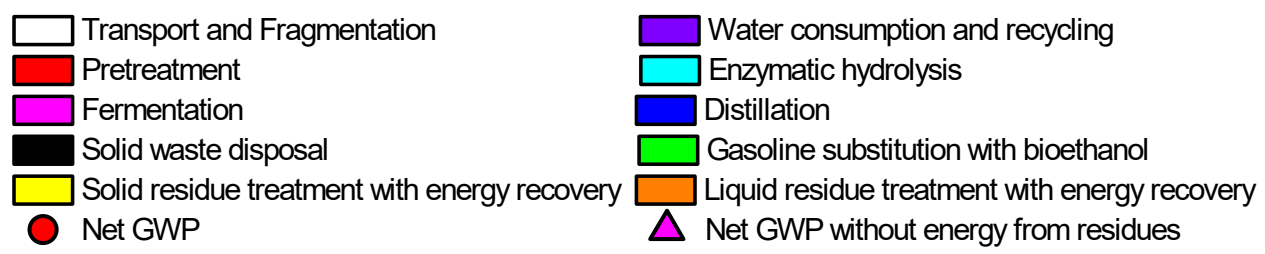

Fig. 2 Global warming potentials of eight technological configurations for producing bioethanol from corn stover, based on individual datasets reported in the literature. (a) S1-Acid (27 cases), (b) S2-Alkaline (19 cases), (c) S3-Solvent-based (14 cases), (d) S4-Steam explosion (17 cases), (e) S5-Liquid hot water (11 cases), (f) S6-Ammonia-based (27 cases), (g) S7-Fungi (11 cases), (h) S8-Combi (15 cases) (Pies and blue numbers on top of the figures indicate the data completeness of each case; red underlined numbers on the top are the maximum values of the bars hitting the border; tables in (c), (g), and (h) list the out-ofrange values of net GWP and net GWP without energy from residues). 
Table 2 presents for each technological configuration the ethanol production per $1000 \mathrm{~kg}$ of dry corn stover as well as net value GWP in terms of average and standard deviation per tonne of corn stover and per liter of bioethanol produced. The GWP per MJ fuel produced is shown in the right column of Table 2.

Table 2 Ethanol production and GWP values (average plus/minus standard deviation) for eight technological configurations per 1 tonne TS of corn stover, per 1 liter of bioethanol produced and per MJ of bioethanol produced

\begin{tabular}{|c|c|c|c|c|c|}
\hline Configuration & $\begin{array}{l}\text { Ethanol } \\
\text { production } \\
(\mathrm{kg} / \mathrm{t} \mathrm{TS})\end{array}$ & $\begin{array}{c}\mathrm{CO}_{2} \text {-eq/t TS of } \\
\text { corn stover } \\
\left(\mathrm{kg} \mathrm{CO}_{2} \text {-eq/t }\right. \\
\mathrm{TS}) \\
\text { Incl. gasoline } \\
\text { substitution }\end{array}$ & $\begin{array}{c}\mathrm{CO}_{2} \text {-eq/t TS of } \\
\text { corn stover } \\
\left(\mathrm{kg} \mathrm{CO} \mathrm{CO}_{2} \text {-eq/t }\right. \\
\mathrm{TS}) \\
\text { Excl. gasoline } \\
\text { substitution }\end{array}$ & $\begin{array}{c}\mathrm{CO}_{2} \text {-eq/L } \\
\text { bioethanol } \\
\text { produced } \\
(\mathrm{kg} \mathrm{CO} \text {-eq/L) } \\
\text { Excl. gasoline } \\
\text { substitution }\end{array}$ & $\begin{array}{c}\mathrm{CO}_{2}-\mathrm{eq} / \mathrm{MJ} \\
\text { bioethanol produced } \\
(\mathrm{kg} \mathrm{CO} \text {-eq/MJ) } \\
\text { Excl. gasoline } \\
\text { substitution }\end{array}$ \\
\hline S1 & $145 \pm 36$ & $-597 \pm 221$ & $-29 \pm 217$ & $-0.3 \pm 1.4$ & $-0.01 \pm 0.06$ \\
\hline $\mathrm{S} 2$ & $201 \pm 45$ & $-581 \pm 269$ & $203 \pm 193$ & $0.9 \pm 1.1$ & $0.036 \pm 0.047$ \\
\hline S3 & $192 \pm 33$ & $8055 \pm 7970$ & $8805 \pm 7981$ & $37 \pm 34$ & $1.6 \pm 1.4$ \\
\hline S4 & $166 \pm 28$ & $-714 \pm 246$ & $-65 \pm 309$ & $-0.5 \pm 1.4$ & $-0.020 \pm 0.058$ \\
\hline S5 & $166 \pm 41$ & $-282 \pm 526$ & $367 \pm 594$ & $1.4 \pm 2.7$ & $0.059 \pm 0.117$ \\
\hline S6 & $218 \pm 47$ & $-598 \pm 400$ & $252 \pm 365$ & $0.9 \pm 1.6$ & $0.039 \pm 0.070$ \\
\hline S7 & $109 \pm 25$ & $-71 \pm 1275$ & $356 \pm 1233$ & $3.6 \pm 11.9$ & $0.15 \pm 0.51$ \\
\hline S8 & $180 \pm 49$ & $-378 \pm 552$ & $711 \pm 588$ & $3.1 \pm 2.5$ & $0.13 \pm 0.11$ \\
\hline
\end{tabular}

Referring to the GWP per tonne of corn stover solids treated, Table 2 reveals that the data reported in the literature on average suggest that the technological configurations S3 (solvent-based pretreatment) and S7 (fungi pretreatment) are not very attractive from a global warming point of view, since the average values are positive or only slightly negative. The very high standard deviation observed might suggest that some of the reported experiments were not successful; actually, the datasets for S3 and S7 showed very high variations.

The technological configuration S4 (steam explosion pretreatment) yielded on average the highest savings in global warming, at around $700 \mathrm{~kg} \mathrm{CO}_{2}-\mathrm{eq} / \mathrm{t} \mathrm{TS}$, but it should be noted that this technology is not among those producing the highest amount of ethanol. Combining both the GWP of converting the corn stover and the amount of bioethanol produced, S2 (alkaline pretreatment) and S6 (ammonia-based pretreatment) on average are the most attractive.

The technological configuration S3 produces high amounts of ethanol by using solvents during pretreatment. The solvent recovery ratios were $88 \% \pm 8 \%$ and the addition of new solvent was found to be a major contributor to GWP. The solvents included tetrahydrofuran (THF), ethylenediamine (EDA), 1-ethyl3-methylimidazolium acetate $([\mathrm{C} 2 \mathrm{mim}][\mathrm{OAc}])$, methyl isobutyl ketone (4-methyl-2-pentanone), acetone, and even ethanol, and their production is a major contribution to GWP ( 2.2 to $6.7 \mathrm{~kg} \mathrm{CO}$-eq $/ \mathrm{kg}$ of solvent) according to the database in Ecoinvent (version 3.3) (see Section A6.3 in the Supplementary Information). In line with our additional results from the Monte Carlo simulations, only an extremely high recovery of 
solvent (>97\%) could make this technology attractive from a global warming point of view (see Section 3.4 and Section A11.2 of Supplementary Information).

The technological configuration S8 also produced high amounts of ethanol but limited savings in GWP, due to a relatively high load to GWP originating from pretreatment, which can be attributed to the complexity of multi-step pretreatment that consumes more energy and chemicals.

The GWP per liter of bioethanol produced or per MJ fuel produced (excluding the savings from the substituted gasoline) reveals that the technological configurations S3 (solvent-based pretreatment), S7 (fungi-pretreatment) and S8 (combi-pretreatment) are less attractive from a GWP perspective, since they in average all exceed the GWP of gasoline, which is $0.086 \mathrm{~kg} \mathrm{CO}_{2}$-eq/MJ conservatively calculated from the corresponding process in Ecoinvent and is $0.093 \mathrm{~kg} \mathrm{CO}$-eq/ $\mathrm{MJ}$ in the regulatory impact analysis by United States Environmental Protection Agency (US EPA) ${ }^{[163]}$. Bioethanol has previously been estimated to have a GWP of 0.010-0.060 $\mathrm{kg} \mathrm{CO}_{2}$-eq/MJ including the footprint of producing the corn stover ${ }^{[26,32,33]}$. The contribution from the feedstock production was not included in the current study since we focused on comparing the technologies for converting corn stover to bioethanol. However, in general S1 (acid pretreatment) and S4 (steam explosion pretreatment) seemed to be lower than reported by others while S2 (alkaline pretreatment), S5 (liquid hot water pretreatment) and S6 (ammonia-based pretreatment) fell within the reported range. As mentioned earlier S3 (solvent-based pretreatment), S7 (fungi pretreatment) and S8 (combi pretreatment) had much higher GWP.

Concluding on the data presented in Table 2 may be a little difficult as to which technology is most promising from a GWP point of view, except that the technologies S3 (solvent-based pretreatment), S7 (fungi pretreatment) and S8 (combi pretreatment) are not recommendable according to the currently available general data. The difficulty in concluding is associated with the fact that we assumed efficient utilization of the residues by incineration and anaerobic digestion and thus large GWP savings from the residue treatment: the less bioethanol produced, the more residue to be utilized, and this corresponds to a large saving as the numerator value (GWP without gasoline substitution) and a small denominator value (amount of bioethanol produced), yielding a high ratio of GWP saved per fuel unit produced. Actually, the ratio indicates that the less bioethanol production the better the GWP footprint. However, this violates the aim of producing bioethanol as a transport fuel substitute. In assessing which technology is most attractive we must pay attention to the amount of bioethanol produced as well as to the overall GWP footprint of the technology.

\subsection{Probability analysis of global warming potentials with Monte Carlo simulations}

The large variations observed in GWP within each technological configuration, and the fact also that the parameters varied across the technological configurations, as reported previously ${ }^{[13]}$, inspired us to develop GWP probability distributions for the seven technological configurations via Monte Carlo simulations. As mentioned earlier, the technological configuration S8 is not included here because the 
multi-process pretreatment with different characteristic parameters could not be represented by simple distributions and any statistical learnings from the analysis could not in a meaningful way be related back to the technological processes involved, and thus would have no value technologically.

Using average corn stover composition and the probability distribution of all process parameters within each of the seven technological configurations (see Section 2.2), 10,000 Monte Carlo simulations were run for each technological configuration of mass flows (including the routing of solid residues to incineration, and liquid residues to anaerobic digestion), and the GWP was determined for each simulation. Since the technological configurations differed primarily in pretreatment and hydrolysis, the sampling of parameters in the fermentation processes was maintained the same for all seven technological configurations. The average mass flows are shown in Section A9.2 of Supplementary Information, including the flows of total solids and water, the input of chemicals and enzymes, as well as the routing of liquid and solid residues. The probability distributions of the GWP are illustrated in Figure 3, including the fitted log normal distribution functions, which proved useful at a 95\% confidence level. Figure 3 also illustrates the expectation values and the mode (the value presenting the highest probability in distribution).

The GWP results for the seven technological configurations presented in Figure 2 and Figure 3 are not fully identical, even though they developed from the same 141 datasets reported in the literature. The difference is seen in that the GWP in Figure 2 illustrates results calculated for specific datasets on corn stover composition and experimental performance, whereas Figure 3 presents simulations based on one corn stover composition (average), using sampling from distributions for each process parameter within each technological configuration, to compare the alternatives from a universal perspective. The outcomes of the 10,000 simulations for each technological configuration appeared log normal distributed, and the characteristic values in terms of the expectation value and the mode were related to the $\log$ normal distribution - in contrast to the average and the standard deviation shown in Table 2. We note that results for all technological configurations are close in the two figures in terms of GWP, except for S5 (liquid hot water pretreatment) and S7 (fungi pretreatment). However, these two technological configurations were also the ones with the fewest observations and the highest variations, thereby exhibiting the widest and most uncertain parameter distributions. We believe that the results in terms of probability distributions based on Monte Carlo simulations (Figure 3) are more generally reliable than the results of specific cases (Figure 2), because average values obtained from Figure 2 are subject to the appearance of outliers not necessarily represented according to their probability. This issue is marginal when 10,000 simulations are included.

The results from the Monte Carlo simulations suggest that S4 (steam explosion) and S6 (ammoniabased) statistically have the greatest probability of yielding the highest savings in GWP when corn stover is converted to bioethanol. The GWP distributions are relatively narrow for S4, S1, S2, and S7, while S3, S5, and S6 show broad GWP distributions with high variations. The technological configurations were compared pair-wise via discernibility analysis, the results for which are shown in detail in Supplementary 
Information. In general, no technological configuration is absolutely better than another, but S3 (solventbased), with its very flat cumulative distribution, is unlikely ever to yield lower GWP than the other alternatives barring any major technological breakthroughs.
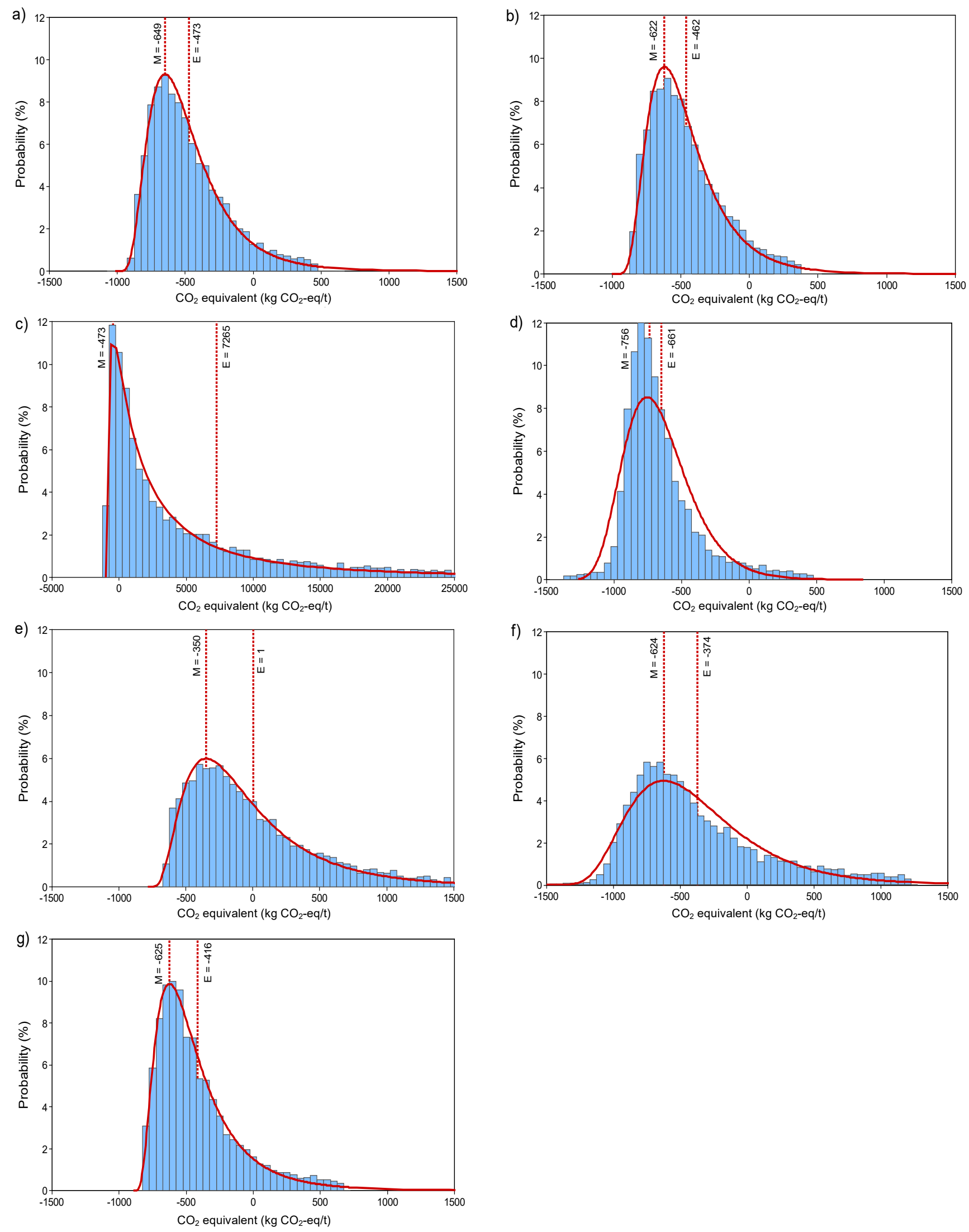

Fig. 3 Global warming potentials of seven technological configurations for producing bioethanol from corn stover, based on Monte Carlo simulations. (a) S1-Acid, (b) S2-Alkaline, (c) S3-Solvent-based, (d) 
S4-Steam explosion, (e) S5-Liquid hot water, (f) S6-Ammonia-based, (g) S7-Fungi (E and M stand for expectation value and mode, respectively. Please note the X-axis of c) S3 is different from the others).

\subsection{Global sensitivity analysis}

Besides the optimization of ethanol production, the GWP will be close to identical for all technological configurations if the pretreatment and hydrolysis processes are optimized and do not use excessive amounts of chemicals, enzymes, or energy, and if the solid and liquid residues are subject to rational energy recovery. To identify the most important variable parameters for improving the various technological configurations, global sensitivity analysis (or known as global importance analysis), which includes the analysis of the fundamental connections between the sensitivity and uncertainty of individual parameters ${ }^{[153]}$, was performed (see Section 2.5).

\subsubsection{Sensitivity ratios and parameter variations}

Highly sensitive parameters were identified by choosing those with a sensitivity ratio above 0.4 ; this means that a parameter that changes by $1 \%$ will positively or negatively affect the result by $0.4 \%$ or higher. Among all the 21 dependent parameters, glucose and ethanol yields in hydrolysis and fermentation, respectively, (GEF_HL and GEF_FT) are the most sensitive in most configurations in terms of a positive relationship to GWP savings (the higher the yields, the more savings). By contrast, enzyme consumption in hydrolysis (BA_HL) is the most sensitive parameter with a negative relationship with savings in most configurations, including S1, S2, S4, S5, and S7, and it is also crucial in S3 and S6.

Besides the common sensitive parameters, the most sensitive are different for different configurations, due to the property of each technological alternative. Specifically, S5 and S4 are considered energysensitive, S7 is xylose-sensitive, while S3 and S6 are chemical-sensitive. S1 shows the properties of both energy-sensitive and chemical-sensitive configurations, and S2 falls in between the chemical-sensitive and xylose-sensitive configurations. The results of the sensitivity ratios and relevant details are shown in Figure A14, Section A10.1 of Supplementary Information.

Based on the fitting of parameter distribution, the variations of each parameter can be calculated to present their dispersion degrees, as shown in Section A8.2 of Supplementary Information. Comparing the variances of each input parameter across the configurations, the higher the variance, the more uncertain the parameter, whereas the lower the variance, the more narrowly the parameter varies. The variances of each parameter are used further for calculating the contribution to the overall variance of results, in order to identify global importance.

\subsubsection{Global parameter sensitivity}

According to the approach described in Section A10.2 of Supplementary Information, the results of the global sensitivity analysis are shown in Table 3. Given the similar property of the processes in each scenario, operational parameters, including temperatures, time, and mixing speed, contribute marginally to 
the variance in overall GWP. Only a few parameters in each scenario that combine high sensitivity to the results and high uncertainty of input data contribute significantly in this regard. Though different important parameters were obtained in different scenarios, some common conclusions can be drawn as follows. Parameters including enzyme consumption, chemical recovery and solid loadings show relatively high importance, due to their sensitivity and the diversity of related processes. For example, enzyme consumption in hydrolysis (BA_HL) is a common and important parameter in almost all the scenarios, due to its high sensitivity and variance, contributing $99 \%$ and $91 \%$ to the GWP uncertainty of S7 and S5, respectively. Olofsson et al. also reported the high sensitivity of enzyme production and utilization on LCA results of ethanol production from wood chips ${ }^{[164]}$. Chemical consumption in pretreatment is quite important to S1, S2, and S3, while chemical recovery is of a good deal of concern in S3 and S6; the former is attributed to high sensitivity with relatively small variance and the latter is ascribed to both sensitivity and variance. Moreover, the parameters of solid loadings in pretreatment and hydrolysis are also major contributors to the variances in the results in some configurations, especially in the energy-sensitive ones like S4, due to the high levels of sensitivity and variance. These results can provide guidance for improving reliability, transparency, and credibility of environmental assessments ${ }^{[165]}$ and thus for prioritizing research by focusing on the really important parameters.

Table 3 Uncertainty contribution analysis of all parameters for all technological configurations (\%) (top four most important parameters in each configuration are underlined)

\begin{tabular}{crrrrrrr}
\hline Parameter & \multicolumn{1}{c}{ S1 } & \multicolumn{1}{c}{ S2 } & \multicolumn{1}{c}{ S3 } & \multicolumn{1}{c}{ S4 } & \multicolumn{1}{c}{ S5 } & \multicolumn{1}{c}{ S6 } & S7 \\
\hline SL_PT & $\underline{3.57}$ & 0.27 & 0.00 & $\underline{11.08}$ & $\underline{3.29}$ & 0.04 & 0.00 \\
SL_PW & 0.02 & 0.17 & 0.00 & 0.02 & $\underline{1.48}$ & 0.00 & 0.00 \\
SL_HL & 0.83 & 0.61 & 0.00 & $\underline{45.56}$ & $\underline{1.38}$ & 0.01 & 0.02 \\
SL_FT & 0.03 & 0.04 & 0.00 & 0.06 & 0.01 & 0.00 & 0.00 \\
GEF_PT & 0.01 & 0.06 & 0.00 & 0.76 & 0.00 & 0.00 & $\underline{0.50}$ \\
GEF_HL & $\underline{5.17}$ & $\underline{3.44}$ & 0.00 & 1.31 & 1.37 & 0.03 & 0.09 \\
GEF_FT & 1.58 & 1.18 & 0.00 & 2.50 & 0.59 & 0.03 & $\underline{0.09}$ \\
XEF_PT & 0.34 & 0.00 & 0.00 & 0.02 & 0.02 & 0.02 & $\underline{0.10}$ \\
XEF_HL & 0.39 & 0.78 & 0.00 & 0.33 & 0.02 & 0.02 & 0.06 \\
XEF_FT & 0.16 & $\underline{1.40}$ & 0.00 & 0.71 & 0.09 & 0.03 & 0.07 \\
LEF_PT & 0.60 & 0.40 & 0.00 & $\underline{12.77}$ & 0.30 & $\underline{1.04}$ & 0.01 \\
T_PT & 0.02 & 0.17 & 0.00 & 0.01 & 0.05 & 0.00 & 0.00 \\
MS_PT & 0.00 & 0.00 & 0.00 & 0.00 & 0.00 & 0.00 & 0.00 \\
MS_HL & 0.17 & 0.00 & 0.00 & 0.41 & 0.00 & 0.00 & 0.00 \\
MS_FT & 0.02 & 0.03 & 0.00 & 0.04 & 0.01 & 0.00 & 0.00 \\
RT_PT & 0.00 & 0.00 & 0.00 & 0.00 & 0.00 & 0.00 & 0.00 \\
RT_HL & 0.25 & 0.02 & 0.00 & 1.33 & 0.01 & 0.01 & 0.00 \\
RT_FT & 0.07 & 0.08 & 0.00 & 0.13 & 0.03 & 0.00 & 0.01 \\
CC_PT & $\underline{37.15}$ & $\underline{14.78}$ & $\underline{31.15}$ & 0.65 & 0.00 & $\underline{1.08}$ & 0.00 \\
CC_HL & 0.00 & 0.00 & 0.00 & 0.00 & 0.00 & 0.00 & 0.00 \\
CR_PT & 0.00 & 0.00 & $\underline{68.85}$ & 0.00 & 0.00 & $\underline{92.89}$ & 0.00 \\
BA_HL & $\underline{49.59}$ & $\underline{76.56}$ & $\underline{0.00}$ & $\underline{22.31}$ & $\underline{91.34}$ & $\underline{4.80}$ & $\underline{99.05}$ \\
Total & 100.00 & 100.00 & 100.00 & 100.00 & 100.00 & 100.00 & 100.00 \\
\hline
\end{tabular}




\section{4 "Best-practice" analysis for each configuration}

Figure 4 illustrates the cumulative probabilities of all of the technological configurations. It is evident that all of the configurations except for S3 and S5 have probabilities over $80 \%$ to contribute savings in GWP (GWP values being negative). It is also notable that many technological configurations cannot reach the benchmark value calculated from the NREL study ${ }^{[36]}$ of $-907 \mathrm{~kg} \mathrm{CO}$-eq/t TS. Statistically less than $15 \%$ of S4 (steam explosion pretreatment) and S6 (ammonia-based pretreatment), as well as only a very small fraction $(<1 \%)$ of S3 (solvent-based pretreatment), S1 (acid pretreatment) and S2 (alkaline pretreatment), can meet the benchmark. It should be noted that the cumulative curve for S3 deviates significantly from the others, and with $80 \%$ probability S3 constitutes no saving in GWP. Discernibility analysis was performed to compare statistically the uncertain results of the technological configurations, as shown in Section A11.1 of Supplementary Information. According to the results of the Monte Carlo simulations, all of the 20\% samples in S3 showing savings in GWP have very high solvent recovery ratios $(96.9 \% \pm 3.8 \%)$; see Section A11.2 of Supplementary Information.

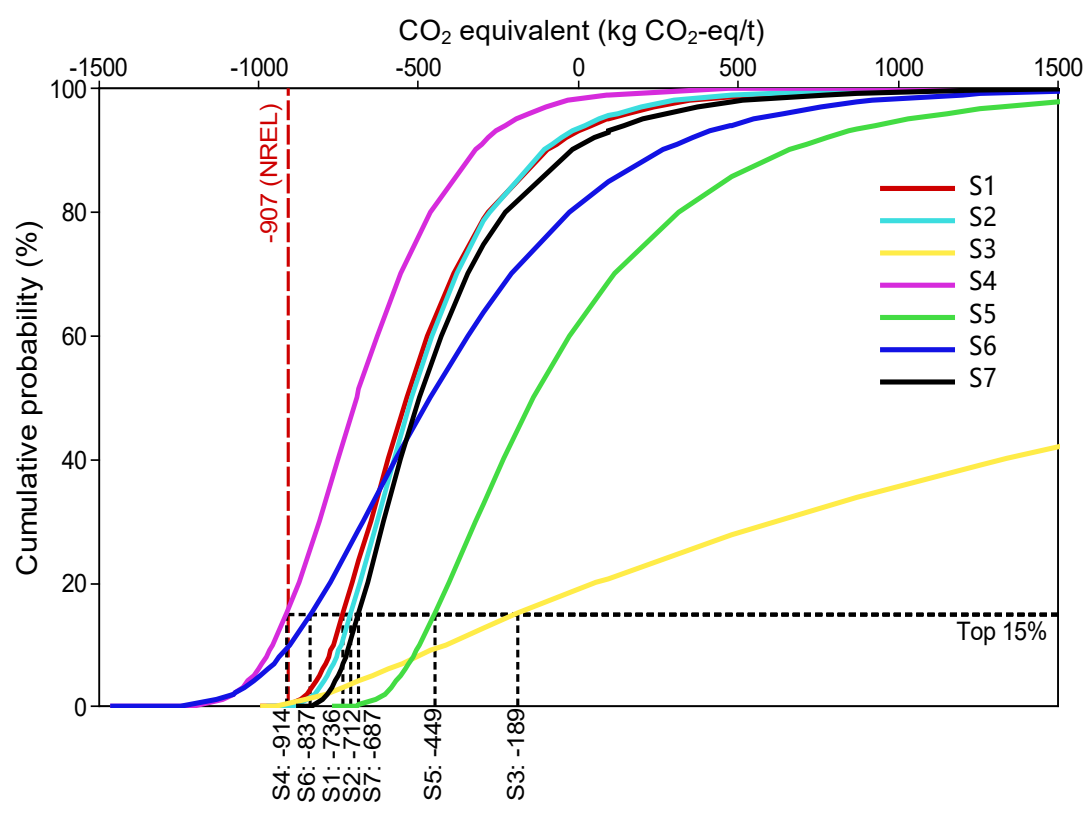

Fig. 4 Cumulative probability of the global warming potentials of Configurations S1-S7.

Figure 4 also illustrates the GWP of the "best-practice" cases with the top 15\% cumulative probability that is considered to represent potential targets for improving the technologies of each configuration. When only considering the "best-practice" cases, S4 and S6 also seem more promising in terms of relatively high ethanol production ( $178 \pm 44 \mathrm{~kg} / \mathrm{t}$ TS and $216 \pm 46 \mathrm{~kg} / \mathrm{t}$ TS, respectively), followed by S1, S2, and S7, while S5 and S3 appear less favorable, though they can also achieve savings in relation to GWP.

The "best-practice" parameters (identified by the Monte Carlo simulation) show many similarities within and across the technological configurations. Table 4 shows for the "best practice" of each technological configuration the average values with standard deviation of the most important parameters in comparison with those for all samples. It is evident that the "best-practice" parameters values that deviate 
the most from the average parameter values are the same as those identified by the global sensitivity analysis in Section 3.3. Specifically, enzyme consumption was lowered on average to $1.7 \times 10^{-2} \mathrm{~kg} / \mathrm{kg}$ TS in most "best-practice" configurations and was much lower than for the global average. To achieve the "best practice" in technological configurations S3 and S6, solvent and ammonia recovery ratios have to be increased to $97.2 \%$ and $98.7 \%$, respectively. Technological configuration S4 requires lower solid loading in hydrolysis but higher in pretreatment, together with a reduction in enzyme consumption. However, S4 seems to have limited room for improvement in GWP, given the low sensitivity ratios of all parameters (Figure A14d in the Supplementary Information). Moreover, less lignin-to-solid feeding to hydrolysis, lower chemical consumption, and higher solid loading in pretreatment seem necessary to achieve better GWP performance in the corresponding configurations. This information indicates the difficulty in achieving "best practice" in each configuration and at the same time the direction for further process optimization within a technological configuration.

Table 4 Values of important parameters assigned to "best practice" compared with overall average values

\begin{tabular}{ccccc}
\hline Configuration & \multicolumn{4}{c}{ Parameter (average plus/minus standard deviation) } \\
\hline S1 & BA_HL $(\mathrm{kg} / \mathrm{kg})$ & CC_PT $(\mathrm{kg} / \mathrm{kg})$ & GEF_HL $(\%)$ & SL_PT $(\%)$ \\
Best $15 \%$ & $1.7 \times 10^{-2} \pm 1.0 \times 10^{-2}$ & $4.8 \times 10^{-2} \pm 3.3 \times 10^{-2}$ & $84.1 \pm 10.0$ & $28.4 \pm 24.0$ \\
Overall & $3.8 \times 10^{-2} \pm 3.9 \times 10^{-2}$ & $1.1 \times 10^{-1} \pm 1.4 \times 10^{-1}$ & $77.7 \pm 18.5$ & $21.7 \pm 23.0$ \\
\hline S2 & BA_HL $(\mathrm{kg} / \mathrm{kg})$ & CC_PT $(\mathrm{kg} / \mathrm{kg})$ & GEF_HL $(\%)$ & XEF_FT $(\%)$ \\
Best $15 \%$ & $1.7 \times 10^{-2} \pm 1.0 \times 10^{-2}$ & $8.1 \times 10^{-2} \pm 3.6 \times 10^{-2}$ & $85.6 \pm 9.7$ & $71.2 \pm 24.4$ \\
Overall & $4.5 \times 10^{-2} \pm 5.5 \times 10^{-2}$ & $1.3 \times 10^{-1} \pm 0.9 \times 10^{-1}$ & $80.0 \pm 18.8$ & $64.1 \pm 36.1$ \\
\hline S3 & CR_PT $(\%)$ & CC_PT $(\mathrm{kg} / \mathrm{kg})$ & BA_HL $(\mathrm{kg} / \mathrm{kg})$ & \\
Best $15 \%$ & $97.2 \pm 3.2$ & $4.3 \pm 4.5$ & $1.7 \times 10^{-2} \pm 1.8 \times 10^{-2}$ & \\
Overall & $78.4 \pm 63.6$ & $16.4 \pm 26.4$ & $2.3 \times 10^{-2} \pm 3.6 \times 10^{-2}$ & \\
\hline S4 & SL_HL $(\%)$ & BA_HL $(\mathrm{kg} / \mathrm{kg})$ & LEF_PT $(\%)$ & SL_PT \\
Best $15 \%$ & $9.6 \pm 6.3$ & $1.6 \times 10^{-2} \pm 1.1 \times 10^{-2}$ & $58.4 \pm 114.0$ & $50.7 \pm 79.7$ \\
Overall & $16.2 \pm 25.6$ & $2.9 \times 10^{-2} \pm 2.1 \times 10^{-2}$ & $84.7 \pm 75.8$ & $29.1 \pm 41.4$ \\
\hline S5 & BA_HL $(\mathrm{kg} / \mathrm{kg})$ & SL_PT $(\%)$ & SL_PW $(\%)$ & SL_HL $(\%)$ \\
Best $15 \%$ & $2.7 \times 10^{-2} \pm 1.4 \times 10^{-2}$ & $7.1 \pm 1.8$ & $3.1 \pm 11.6$ & $5.9 \pm 5.3$ \\
Overall & $7.2 \times 10^{-2} \pm 8.8 \times 10^{-2}$ & $6.0 \pm 2.3$ & $2.3 \pm 10.1$ & $5.6 \pm 9.2$ \\
\hline S6 & CR_PT $(\%)$ & BA_HL $(\mathrm{kg} / \mathrm{kg})$ & CC_PT $(\mathrm{kg} / \mathrm{kg})$ & LEF_PT $(\%)$ \\
Best $15 \%$ & $98.7 \pm 2.3$ & $1.9 \times 10^{-2} \pm 2.1 \times 10^{-2}$ & $2.1 \pm 1.3$ & $11.9 \pm 188.0$ \\
Overall & $91.0 \pm 31.7$ & $6.2 \times 10^{-2} \pm 8.9 \times 10^{-2}$ & $2.3 \pm 1.3$ & $57.4 \pm 144.8$ \\
\hline S7 & BA_HL $(\mathrm{kg} / \mathrm{kg})$ & GEF_PT $(\%)$ & XEF_PT $(\%)$ & GEF_FT $(\%)$ \\
Best $15 \%$ & $0.9 \times 10^{-2} \pm 0.7 \times 10^{-2}$ & $91.4 \pm 6.2$ & $69.5 \pm 13.5$ & $89.2 \pm 9.6$ \\
Overall & $7.0 \times 10^{-2} \pm 16.5 \times 10^{-2}$ & $82.0 \pm 23.9$ & $60.1 \pm 22.6$ & $85.8 \pm 15.5$ \\
\hline
\end{tabular}

\subsection{Scenario uncertainty analysis with different background energy mixes}

Given that America and China are the leading corn - and thus corn stover-producers in the world, a scenario uncertainty analysis was performed to reveal the impacts of differences in the energy used in the two countries. Figure 5 compares the GWP results for scenarios involving American (USA), Chinese $(\mathrm{CHN})$, and default (DF) energy mixes for electricity and heat (see Section A6.2 of Supplementary Information) for technological configurations S1, S2, S4, S6, and S7, which were identified above as the 
most promising configurations. When the energy mix used in an LCA is shifted to that of USA and CHN, these configurations can produce more savings for the GWP, because the energy recovered from the anaerobic digestion and incineration of the residues now substitutes for more fossil-dominated energy. This indicates that energy recovery from the residues plays a more important role in the entire system when aligned with the USA and CHN energy mixes. Furthermore, in the USA and CHN energy mix scenarios, the histograms become flatter than for the DF energy mix, presenting higher variances in terms of the GWP results. This is attributed to the variance amplification of the greater weight of energy substitution, especially for energy-sensitive configurations like S4 and S1.

When the background energy mix was changed, the favorability of the technological configurations also changed from a global warming perspective, due to the different sensitivities of the energy mix in different configurations. This implies that the energy background is so crucial that it may affect the technological selection by affecting the GWP related to energy recovery from the residues. Those countries and regions already with quite clean energy mixes may favor technologies that produce high amounts of bioethanol, whereas those still in transition from non-clean energy mixes should give preference to technologies with high overall GWP savings.
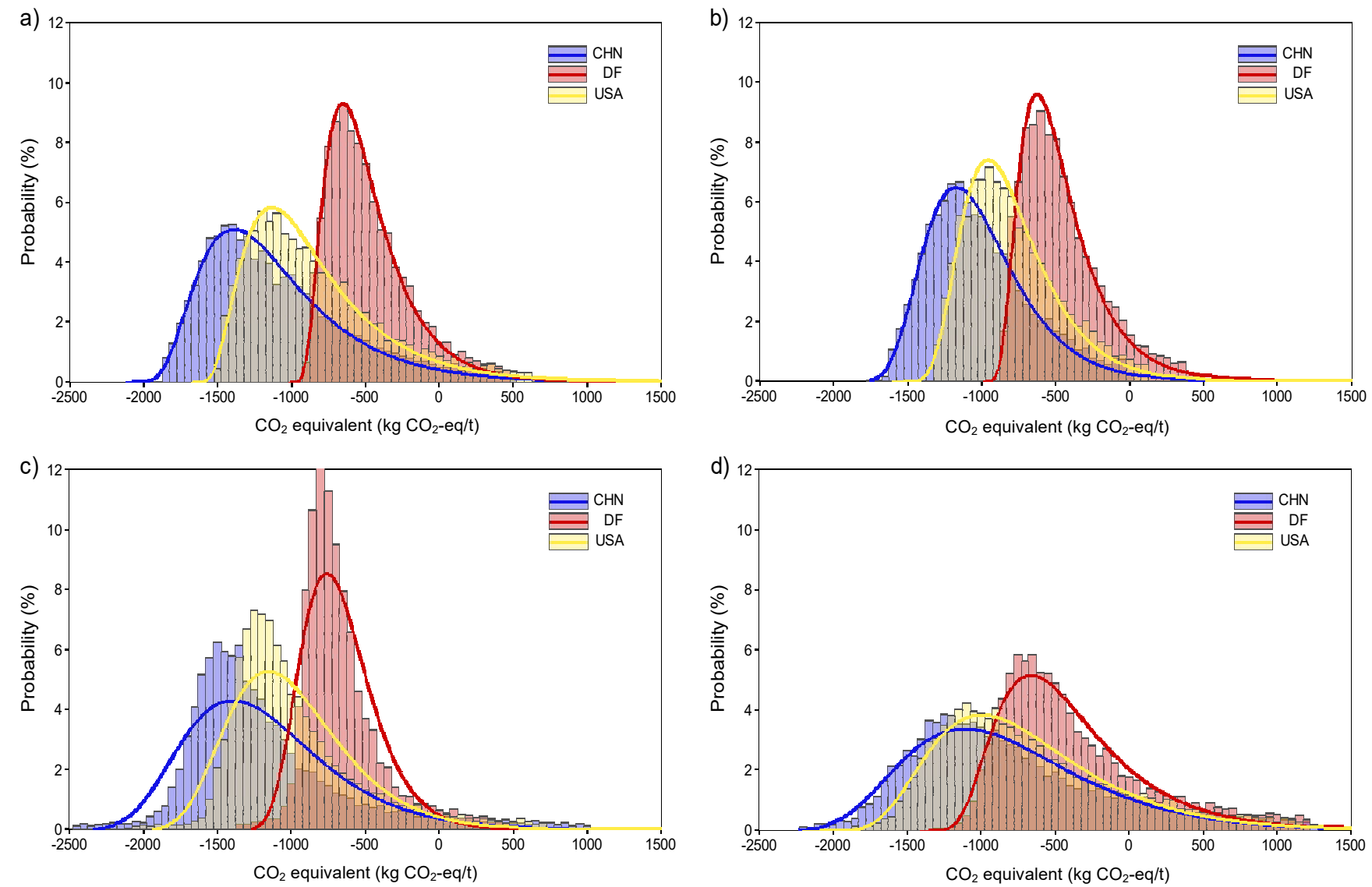


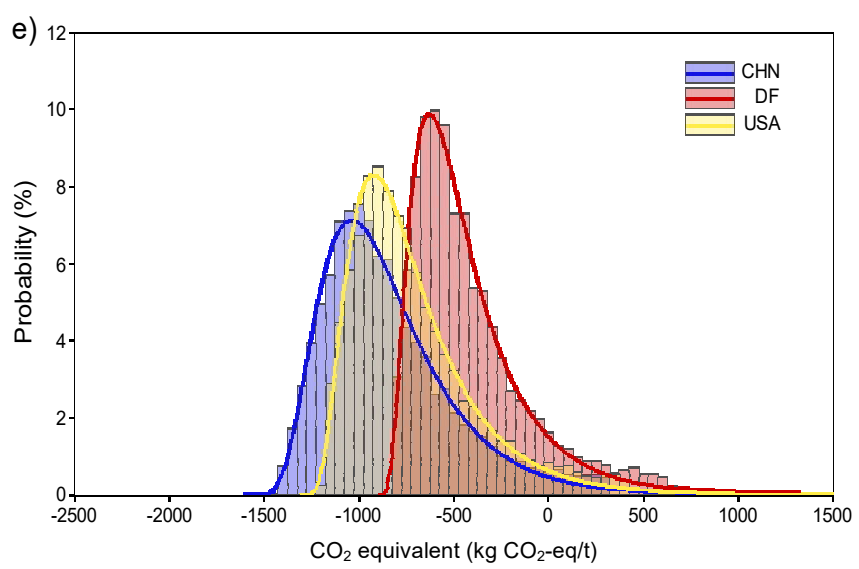

Fig. 5 Scenario uncertainty for global warming potentials with average American (USA) and Chinese (CHN) energy mixes compared to the default (DF) energy mix. (a) S1-Acid, (b) S2-Alkaline, (c) S4Steam explosion, (d) S6-Ammonia-based, (e) S7-Fungi.

\section{Conclusions}

Aiming to identify the most sustainable technologies for bioethanol production from corn stover from a global warming perspective, a systematic life cycle assessment, enhanced with statistics and probability approaches, was performed on seven alternative technological configurations. The global warming potential (GWP) results indicate that most technological configurations generally contribute to savings in global warming impacts, due to substituting gasoline with bioethanol and recovering energy from residue treatment. The energy and chemicals used in pretreatment, together with the energy and enzymes used in hydrolysis, are major contributors to the GWP loads. Large variations were observed in the GWP of each technological configuration, because the parameters reported in the literature varied significantly. Based on the probability distribution of all process parameters in each configuration, Monte Carlo simulations of the mass flows and GWP savings suggest that bioethanol production from corn stover, via steam explosion and ammonia-based pretreatment, statistically has the greatest probability of yielding the highest savings in GWP, but no technological configuration is absolutely better than another alternative.

From global sensitivity analysis, only a few parameters in each scenario were found to contribute to the variance in the overall GWP result. In general, enzyme consumption in hydrolysis is the most important parameter in nearly all of the technological configurations and contributes significantly as a load to the net GWP. Additionally, the consumption and recovery of chemicals in pretreatment are quite important to the GWPs of technologies using acid, solvent-, and ammonia-based pretreatment. The "best-practice" cases with top $15 \%$ cumulative probability among the 10,000 Monte Carlo simulations indicate that technological configurations with steam explosion and ammonia-based pretreatment are the most promising from a global warming perspective. Savings as high as $850 \sim 1050 \mathrm{~kg} \mathrm{CO}$-eq/t TS of corn stover could be obtained, but only if energy was recovered from the liquid and solid residues. The "best-practice" cases indicate that further research should focus on enzyme and chemical consumption, enhancing chemical recovery, and 
optimizing the conversion coefficients in pretreatment and hydrolysis. The robustness of the GWP results was supported by the statistical assessment, but it is worth noting that the energy background is so crucial that it may affect the technological selection by affecting the GWP related to energy performance. These results profile the most sustainable processes for producing bioethanol from a global warming perspective and highlight where further research and development are needed.

\section{Conflicts of interest}

The authors declare no conflicts of interest.

\section{Acknowledgements}

This work was supported financially by the National Natural Science Foundation of China (No. 51578071) and the China Scholar Council (201606045038). The authors would also like to express their sincere gratitude to Dr. Valentina Bisinella and Dr. Davide Tonini, Department of Environmental Engineering, Technical University of Denmark, for their helpful advice on the research ideas and approaches.

\section{Electronic Supplementary Information}

Electronic Supplementary Information associated with this article can be found in the online version: Source data; screened references as data source; calculation of energy consumption; calculation of fuel consumption and substitution; calculation of enzyme consumption and production; treatment of separated liquid and solid residues; life cycle inventory (LCI) data for external processes; case-specific global warming potentials (GWPs) of the configurations; distribution fitting and uncertainty of the input parameter data; mass flow of the process configurations; global sensitivity analysis; uncertainty analysis with parameter distribution.

\section{Reference}

[1] Wojtusik M, Zurita M, Villar JC, Ladero M, Garcia-Ochoa F. Influence of fluid dynamic conditions on enzymatic hydrolysis of lignocellulosic biomass: Effect of mass transfer rate. Bioresource Technology, 2016. 216, 28-35.

[2] Morales M, Quintero J, Conejeros R, Aroca G. Life cycle assessment of lignocellulosic bioethanol: Environmental impacts and energy balance. Renewable \& Sustainable Energy Reviews, 2015. 42, 1349-1361.

[3] Soam S, Kapoor M, Kumar R, Borjesson P, Gupta RP, Tuli DK. Global warming potential and energy analysis of second generation ethanol production from rice straw in India. Applied Energy, 2016. 184, 353-364.

[4] Tao L, Markham JN, Haq Z, Biddy MJ. Techno-economic analysis for upgrading the biomassderived ethanol-to-jet blendstocks. Green Chemistry, 2017. 19, 1082-1101. 
[5] Zhao LL, Ou XM, Chang SY. Life-cycle greenhouse gas emission and energy use of bioethanol produced from corn stover in China: Current perspectives and future prospectives. Energy, 2016. $115,303-313$.

[6] Loow YL, Wu TY, Jahim JM, Mohammad AW, Teoh WH. Typical conversion of lignocellulosic biomass into reducing sugars using dilute acid hydrolysis and alkaline pretreatment. Cellulose, 2016. 23, 1491-1520.

[7] Kumar R, Tabatabaei M, Karimi K, Horvath IS. Recent updates on lignocellulosic biomass derived ethanol - A review. Biofuel Research Journal-BRJ, 2016. 3, 347-356.

[8] Capolupo L, Faraco V. Green methods of lignocellulose pretreatment for biorefinery development. Applied Microbiology and Biotechnology, 2016. 100, 9451-9467.

[9] Wilhelm WW, Johnson JME, Karlen DL, Lightle DT. Corn stover to sustain soil organic carbon further constrains Biomass supply. Agronomy Journal, 2007. 99, 1665-1667.

[10] Richard TL. Challenges in Scaling Up Biofuels Infrastructure. Science, 2010. 329, 793-796.

[11] Das S, Peterson B, Chin SM. Analysis of fuel ethanol transportation activity and potential distribution constraints. Transportation Research Record, 2010, 136-145.

[12] Zabed H, Sahu JN, Boyce AN, Faruq G. Fuel ethanol production from lignocellulosic biomass: An overview on feedstocks and technological approaches. Renewable \& Sustainable Energy Reviews, 2016. 66, 751-774.

[13] Zhao Y, Damgaard A, Christensen TH. Bioethanol from corn stover - a review and technical assessment of alternative biotechnologies. Progress in Energy and Combustion Science, 2018. 67, 275-291.

[14] Adler PR, Del Grosso SJ, Parton WJ. Life-cycle assessment of net greenhouse-gas flux for bioenergy cropping systems. Ecological Applications, 2007. 17, 675-691.

[15] McKechnie J, Pourbafrani M, Saville BA, MacLean HL. Exploring impacts of process technology development and regional factors on life cycle greenhouse gas emissions of corn stover ethanol. Renewable Energy, 2015. 76, 726-734.

[16] Liska AJ, Yang HS, Milner M, Goddard S, Blanco-Canqui H, Pelton MP, Fang XX, Zhu HT, Suyker AE. Biofuels from crop residue can reduce soil carbon and increase $\mathrm{CO}_{2}$ emissions. Nature Climate Change, 2014. 4, 398-401.

[17] Yan XY, Inderwildi OR, King DA, Boies AM. Effects of ethanol on vehicle energy efficiency and implications on ethanol life-cycle greenhouse gas analysis. Environmental Science \& Technology, 2013. 47, 5535-5544.

[18] Zhu LJ, Guo WW, Yin S, Wang SR. Comparative life cycle assessment of ethanol synthesis from corn stover by direct and indirect thermochemical conversion processes. Energy \& Fuels, 2015. 29, 7998-8005.

[19] Mu DY, Seager T, Rao PS, Zhao F. Comparative life cycle assessment of lignocellulosic ethanol production: Biochemical versus thermochemical conversion. Environmental Management, 2010. 46, 565-578.

[20] Hong JM, Zhou J, Hong JL. Comparative study of life cycle environmental and economic impact of corn- and corn stalk-based-ethanol production. Journal of Renewable and Sustainable Energy, 2015. 7, 16.

[21] Daylan B, Ciliz N. Life cycle assessment and environmental life cycle costing analysis of lignocellulosic bioethanol as an alternative transportation fuel. Renewable Energy, 2016. 89, 578587.

[22] Zucaro A, Forte A, Fierro A. Life cycle assessment of wheat straw lignocellulosic bio-ethanol fuel in a local biorefinery prospective. Journal of Cleaner Production, 2018. 194, 138-149.

[23] Jeswani HK, Falano T, Azapagic A. Life cycle environmental sustainability of lignocellulosic ethanol produced in integrated thermo-chemical biorefineries. Biofuels Bioproducts \& BiorefiningBiofpr, 2015. 9, 661-676.

[24] Chang FC, Lin LD, Ko CH, Hsieh HC, Yang BY, Chen WH, Hwang WS. Life cycle assessment of bioethanol production from three feedstocks and two fermentation waste reutilization schemes. Journal of Cleaner Production, 2017. 143, 973-979. 
[25] Trivedi P, Malina R, Barrett SRH. Environmental and economic tradeoffs of using corn stover for liquid fuels and power production. Energy \& Environmental Science, 2015. 8, 1428-1437.

[26] Mullins KA, Griffin WM, Matthews HS. Policy implications of uncertainty in modeled life-cycle greenhouse gas emissions of biofuels. Environmental Science \& Technology, 2011. 45, 132-138.

[27] Murphy CW, Kendall A. Life cycle analysis of biochemical cellulosic ethanol under multiple scenarios. Global Change Biology Bioenergy, 2015. 7, 1019-1033.

[28] Pourhashem G, Adler PR, McAloon AJ, Spatari S. Cost and greenhouse gas emission tradeoffs of alternative uses of lignin for second generation ethanol. Environmental Research Letters, 2013. 8, 13.

[29] Spatari S, Bagley DM, MacLean HL. Life cycle evaluation of emerging lignocellulosic ethanol conversion technologies. Bioresource Technology, 2010. 101, 654-667.

[30] Neupane B, Konda N, Singh S, Simmons BA, Scown CD. Life-cycle greenhouse gas and water intensity of cellulosic biofuel production using cholinium lysinate ionic liquid pretreatment. Acs Sustainable Chemistry \& Engineering, 2017. 5, 10176-10185.

[31] Posen ID, Jaramillo P, Griffin WM. Uncertainty in the life cycle greenhouse gas emissions from U.S. production of three biobased polymer families. Environmental Science \& Technology, 2016. 50, 2846-2858.

[32] Spatari S, MacLean HL. Characterizing model uncertainties in the life cycle of lignocellulose-based ethanol fuels. Environmental Science \& Technology, 2010. 44, 8773-8780.

[33] Hsu DD, Inman D, Heath GA, Wolfrum EJ, Mann MK, Aden A. Life cycle environmental impacts of selected U.S. ethanol production and use pathways in 2022. Environmental Science \& Technology, 2010. 44, 5289-5297.

[34] Vicari KJ, Tallam SS, Shatova T, Joo KK, Scarlata CJ, Humbird D, Wolfrum EJ, Beckham GT. Uncertainty in techno-economic estimates of cellulosic ethanol production due to experimental measurement uncertainty. Biotechnology for Biofuels, 2012. 5, 23-34.

[35] Nguyen L, Cafferty KG, Searcy EM, Spatari S. Uncertainties in life cycle greenhouse gas emissions from advanced biomass feedstock logistics supply chains in Kansas. Energies, 2014. 7, 7125-7146.

[36] Tao L, Schell D, Davis R, Tan E, Elander R, Bratis A, NREL 2012 Achievement of ethanol cost targets: Biochemical ethanol fermentation via dilute-acid pretreatment and enzymatic hydrolysis of corn stover. 2014, National Renewable Energy Laboratory.

[37] Li P, Cai D, Luo ZF, Qin PY, Chen CJ, Wang Y, Zhang CW, Wang Z, Tan TW. Effect of acid pretreatment on different parts of corn stalk for second generation ethanol production. Bioresource Technology, 2016. 206, 86-92.

[38] Nguyen TY, Cai CM, Osman O, Kumar R, Wyman CE. CELF pretreatment of corn stover boosts ethanol titers and yields from high solids SSF with low enzyme loadings. Green Chemistry, 2016. 18, 1581-1589.

[39] Yu H, Ren JW, Liu L, Zheng ZJ, Zhu JJ, Yong Q, Ouyang J. A new magnesium bisulfite pretreatment (MBSP) development for bio-ethanol production from corn stover. Bioresource Technology, 2016. 199, 188-193.

[40] Liu K, Zhang J, Bao J. Two stage hydrolysis of corn stover at high solids content for mixing power saving and scale-up applications. Bioresource Technology, 2015. 196, 716-720.

[41] Liu ZL, Cotta MA. Technical assessment of cellulosic ethanol production using beta-Glucosidase producing yeast Clavispora NRRL Y-50464. Bioenergy Research, 2015. 8, 1203-1211.

[42] Nguyen TY, Cai CM, Kumar R, Wyman CE. Co-solvent pretreatment reduces costly enzyme requirements for high sugar and ethanol yields from lignocellulosic biomass. Chemsuschem, 2015. $8,1716-1725$.

[43] Xue SS, Uppugundla N, Bowman MJ, Cavalier D, Sousa LDC, Dale BE, Balan V. Sugar loss and enzyme inhibition due to oligosaccharide accumulation during high solids-loading enzymatic hydrolysis. Biotechnology for Biofuels, 2015. 8, 195-208.

[44] Zhang Q, Zhang PF, Pei ZJ, Xu F, Wang DH, Vadlani P. Effects of ultrasonic vibration-assisted pelleting on chemical composition and sugar yield of corn stover and sorghum stalk. Renewable Energy, 2015. 76, 160-166. 
[45] Gao XD, Kumar R, Singh S, Simmons BA, Balan V, Dale BE, Wyman CE. Comparison of enzymatic reactivity of corn stover solids prepared by dilute acid, AFEX (TM), and ionic liquid pretreatments. Biotechnology for Biofuels, 2014. 7, 71-83.

[46] He YQ, Zhang J, Bao J. Dry dilute acid pretreatment by co-currently feeding of corn stover feedstock and dilute acid solution without impregnation. Bioresource Technology, 2014. 158, 360364.

[47] He YQ, Zhang LP, Zhang J, Bao J. Helically agitated mixing in dry dilute acid pretreatment enhances the bioconversion of corn stover into ethanol. Biotechnology for Biofuels, 2014. 7, 1-13.

[48] Tai C, Keshwani D. Impact of pretreatment with dilute sulfuric acid under moderate temperature on hydrolysis of corn stover with two enzyme systems. Applied Biochemistry and Biotechnology, 2014. $172,2628-2639$.

[49] Uppugundla N, Sousa LD, Chundawat SPS, Yu XR, Simmons B, Singh S, Gao XD, Kumar R, Wyman CE, Dale BE, Balan V. A comparative study of ethanol production using dilute acid, ionic liquid and AFEX (TM) pretreated corn stover. Biotechnology for Biofuels, 2014. 7, 72-85.

[50] Yu H, Zhang M, Ouyang J, Shen Y. Comparative study on four chemical pretreatment methods for an efficient saccharification of corn stover. Energy \& Fuels, 2014. 28, 4282-4287.

[51] Yu G, Li B, Liu C, Zhang YD, Wang HS, Mu XD. Fractionation of the main components of corn stover by formic acid and enzymatic saccharification of solid residue. Industrial Crops and Products, 2013. 50, 750-757.

[52] Chen Y, Stevens MA, Zhu YM, Holmes J, Moxley G, Xu H. Reducing acid in dilute acid pretreatment and the impact on enzymatic saccharification. Journal of Industrial Microbiology \& Biotechnology, 2012. 39, 691-700.

[53] Theerarattananoon K, Xu F, Wilson J, Staggenborg S, McKinney L, Vadlani P, Pei ZJ, Wang DH. Effects of the pelleting conditions on chemical composition and sugar yield of corn stover, big bluestem, wheat straw, and sorghum stalk pellets. Bioprocess and Biosystems Engineering, 2012. $35,615-623$.

[54] Yoo CG, Kuo M, Kim TH. Ethanol and furfural production from corn stover using a hybrid fractionation process with zinc chloride and simultaneous saccharification and fermentation (SSF). Process Biochemistry, 2012. 47, 319-326.

[55] Shi J, Pu YQ, Yang B, Ragauskas A, Wyman CE. Comparison of microwaves to fluidized sand baths for heating tubular reactors for hydrothermal and dilute acid batch pretreatment of corn stover. Bioresource Technology, 2011. 102, 5952-5961.

[56] Van Eylen D, van Dongen F, Kabel M, de Bont J. Corn fiber, cobs and stover: Enzyme-aided saccharification and co-fermentation after dilute acid pretreatment. Bioresource Technology, 2011. 102, 5995-6004.

[57] Qing Q, Yang B, Wyman CE. Impact of surfactants on pretreatment of corn stover. Bioresource Technology, 2010. 101, 5941-5951.

[58] Chen M, Zhao J, Xia LM. Comparison of four different chemical pretreatments of corn stover for enhancing enzymatic digestibility. Biomass \& Bioenergy, 2009. 33, 1381-1385.

[59] Lau MW, Gunawan C, Dale BE. The impacts of pretreatment on the fermentability of pretreated lignocellulosic biomass: A comparative evaluation between ammonia fiber expansion and dilute acid pretreatment. Biotechnology for Biofuels, 2009. 2, 30-40.

[60] Hodge DB, Karim MN, Schell DJ, McMillan JD. Soluble and insoluble solids contributions to highsolids enzymatic hydrolysis of lignocellulose. Bioresource Technology, 2008. 99, 8940-8948.

[61] Kuhn EM, O'Brien MH, Ciesielski PN, Schell DJ. Pilot-scale batch alkaline pretreatment of corn stover. ACS Sustainable Chemistry \& Engineering, 2016. 4, 944-956.

[62] Liu H, Pang B, Wang HS, Li HM, Lu J, Niu MH. Optimization of alkaline sulfite pretreatment and comparative study with sodium hydroxide pretreatment for improving enzymatic digestibility of corn stover. Journal of Agricultural and Food Chemistry, 2015. 63, 3229-3234.

[63] Xu HF, Yu G, Mu XD, Zhang CY, DeRoussel P, Liu C, Li B, Wang HS. Effect and characterization of sodium lignosulfonate on alkali pretreatment for enhancing enzymatic saccharification of corn stover. Industrial Crops and Products, 2015. 76, 638-646. 
[64] Chen XW, Shekiro J, Pschorn T, Sabourin M, Tao L, Elander R, Park S, Jennings E, Nelson R, Trass O, Flanegan K, Wang W, Himmel ME, Johnson D, Tucker MP. A highly efficient dilute alkali deacetylation and mechanical (disc) refining process for the conversion of renewable biomass to lower cost sugars. Biotechnology for Biofuels, 2014. 7, 98-108.

[65] Chu QL, Huang Y, Li X, Fan YM, Jin YC, Yu SY, Yong Q. Improved enzymatic hydrolysis of corn stover by green liquor pretreatment and a specialized enzyme cocktail. Bioresources, 2014. 9, 44894502.

[66] Chu QL, Li X, Yang DL, Xu Y, Ouyang J, Yu SY, Yong Q. Corn stover bioconversion by green liquor pretreatment and a selected liquid fermentation strategy. Bioresources, 2014. 9, 7681-7695.

[67] Karp EM, Donohoe BS, O'Brien MH, Ciesielski PN, Mittal A, Biddy MJ, Beckham GT. Alkaline pretreatment of corn stover: Bench-scale fractionation and stream characterization. ACS Sustainable Chemistry \& Engineering, 2014. 2, 1481-1491.

[68] Peng HD, Luo H, Jin SY, Li HQ, Xu J. Improved bioethanol production from corn stover by alkali pretreatment with a novel pilot-scale continuous microwave irradiation reactor. Biotechnology and Bioprocess Engineering, 2014. 19, 493-502.

[69] Zhao XZ, Liang XX, Han SQ, Uryu T, Yoshida T. Successive saccharification and fermentation of cellulosic agricultural residues using a combination of cellulase and recombinant yeast. Sen-I Gakkaishi, 2014. 70, 191-196.

[70] Chen Y, Stevens MA, Zhu YM, Holmes J, Xu H. Understanding of alkaline pretreatment parameters for corn stover enzymatic saccharification. Biotechnology for Biofuels, 2013. 6, 8-17.

[71] Guragain YN, Wilson J, Staggenborg S, McKinney L, Wang DH, Vadlani PV. Evaluation of pelleting as a pre-processing step for effective biomass deconstruction and fermentation. Biochemical Engineering Journal, 2013. 77, 198-207.

[72] Banerjee G, Car S, Liu TJ, Williams DL, Meza SL, Walton JD, Hodge DB. Scale-up and integration of alkaline hydrogen peroxide pretreatment, enzymatic hydrolysis, and ethanolic fermentation. Biotechnology and Bioengineering, 2012. 109, 922-931.

[73] Cui ZF, Shi J, Wan CX, Li YB. Comparison of alkaline- and fungi-assisted wet-storage of corn stover. Bioresource Technology, 2012. 109, 98-104.

[74] Li Q, Gao Y, Wang HS, Li B, Liu C, Yu G, Mu XD. Comparison of different alkali-based pretreatments of corn stover for improving enzymatic saccharification. Bioresource Technology, 2012. 125, 193-199.

[75] Zhang XM, Xu JL, Cheng JJ. Pretreatment of corn stover for sugar production with combined alkaline reagents. Energy \& Fuels, 2011. 25, 4796-4802.

[76] Rodgers M, Hu ZH, Zhan XM. Enhancing enzymatic hydrolysis of maize stover by bayer process sand pretreatment. Energy \& Fuels, 2009. 23, 2284-2289.

[77] Baral NR, Shah A. Techno-economic analysis of cellulose dissolving ionic liquid pretreatment of lignocellulosic biomass for fermentable sugars production. Biofuels Bioproducts \& BiorefiningBiofpr, 2016. 10, 70-88.

[78] Papa G, Rodriguez S, George A, Schievano A, Orzi V, Sale KL, Singh S, Adani F, Simmons BA. Comparison of different pretreatments for the production of bioethanol and biomethane from corn stover and switchgrass. Bioresource Technology, 2015. 183, 101-110.

[79] Qin L, Li WC, Zhu JQ, Liang JN, Li BZ, Yuan YJ. Ethylenediamine pretreatment changes cellulose allomorph and lignin structure of lignocellulose at ambient pressure. Biotechnology for Biofuels, 2015. 8, 174-188.

[80] Katahira R, Mittal A, McKinney K, Ciesielski PN, Donohoe BS, Black SK, Johnson DK, Biddy MJ, Beckham GT. Evaluation of clean fractionation pretreatment for the production of renewable fuels and chemicals from corn stover. ACS Sustainable Chemistry \& Engineering, 2014. 2, 1364-1376.

[81] Resch MG, Donohoe BS, Ciesielski PN, Nill JE, Magnusson L, Himmel ME, Mittal A, Katahira R, Biddy MJ, Beckham GT. Clean fractionation pretreatment reduces enzyme loadings for biomass saccharification and reveals the mechanism of free and cellulosomal enzyme synergy. ACS Sustainable Chemistry \& Engineering, 2014. 2, 1377-1387. 
[82] Xu F, Shi YC, Wang DH. Enhanced production of glucose and xylose with partial dissolution of corn stover in ionic liquid, 1-Ethyl-3-methylimidazolium acetate. Bioresource Technology, 2012. $114,720-724$.

[83] Dibble DC, Li CL, Sun L, George A, Cheng ARL, Cetinkol OP, Benke P, Holmes BM, Singh S, Simmons BA. A facile method for the recovery of ionic liquid and lignin from biomass pretreatment. Green Chemistry, 2011. 13, 3255-3264.

[84] Li CL, Cheng G, Balan V, Kent MS, Ong M, Chundawat SPS, Sousa LD, Melnichenko YB, Dale BE, Simmons BA, Singh S. Influence of physico-chemical changes on enzymatic digestibility of ionic liquid and AFEX pretreated corn stover. Bioresource Technology, 2011. 102, 6928-6936.

[85] Zhang YHP, Ding SY, Mielenz JR, Cui JB, Elander RT, Laser M, Himmel ME, McMillan JR, Lynd LR. Fractionating recalcitrant lignocellulose at modest reaction conditions. Biotechnology and Bioengineering, 2007. 97, 214-223.

[86] Liu ZH, Chen HZ. Periodic peristalsis enhancing the high solids enzymatic hydrolysis performance of steam exploded corn stover biomass. Biomass \& Bioenergy, 2016. 93, 13-24.

[87] Liu ZH, Chen HZ. Periodic peristalsis releasing constrained water in high solids enzymatic hydrolysis of steam exploded corn stover. Bioresource Technology, 2016. 205, 142-152.

[88] Liu ZH, Chen HZ. Simultaneous saccharification and co-fermentation for improving the xylose utilization of steam exploded corn stover at high solid loading. Bioresource Technology, 2016. 201, 15-26.

[89] Bondesson PM, Dupuy A, Galbe M, Zacchi G. Optimizing ethanol and methane production from steam-pretreated, phosphoric acid-impregnated corn stover. Applied Biochemistry and Biotechnology, 2015. 175, 1371-1388.

[90] Liu ZH, Chen HZ. Xylose production from corn stover biomass by steam explosion combined with enzymatic digestibility. Bioresource Technology, 2015. 193, 345-356.

[91] Mo CL, Chen N, Lv T, Du JL, Tian S. Direct ethanol production from steam-exploded corn stover using a synthetic diploid cellulase-displaying yeast consortium. Bioresources, 2015. 10, 4460-4472.

[92] De Bari I, Cuna D, Di Matteo V, Liuzzi F. Bioethanol production from steam-pretreated corn stover through an isomerase mediated process. New Biotechnology, 2014. 31, 185-195.

[93] Liu ZH, Qin L, Zhu JQ, Li BZ, Yuan YJ. Simultaneous saccharification and fermentation of steamexploded corn stover at high glucan loading and high temperature. Biotechnology for Biofuels, 2014 7, 167-182.

[94] Rana V, Eckard AD, Ahring BK. Comparison of SHF and SSF of wet exploded corn stover and loblolly pine using in-house enzymes produced from T. reesei RUT C30 and A. saccharolyticus. Springerplus, 2014. 3, 13.

[95] Wang Z, Lv Z, Du J, Mo C, Yang X, Tian S. Combined process for ethanol fermentation at highsolids loading and biogas digestion from unwashed steam-exploded corn stover. Bioresource Technology, 2014. 166, 282-287.

[96] Bondesson PM, Galbe M, Zacchi G. Ethanol and biogas production after steam pretreatment of corn stover with or without the addition of sulphuric acid. Biotechnology for Biofuels, 2013. 6, 11-21.

[97] Liu ZH, Qin L, Pang F, Jin MJ, Li BZ, Kang Y, Dale BE, Yuan YJ. Effects of biomass particle size on steam explosion pretreatment performance for improving the enzyme digestibility of corn stover. Industrial Crops and Products, 2013. 44, 176-184.

[98] Pang F, Xue SL, Yu SS, Zhang C, Li B, Kang Y. Effects of combination of steam explosion and microwave irradiation (SE-MI) pretreatment on enzymatic hydrolysis, sugar yields and structural properties of corn stover. Industrial Crops and Products, 2013. 42, 402-408.

[99] Tian S, Li Y, Wang Z, Yang XS. Evaluation of simultaneous saccharification and ethanol fermentation of undetoxified steam-exploded corn stover by Saccharomyces cerevisiae Y5. Bioenergy Research, 2013. 6, 1142-1146.

[100] Yu YL, Feng YJ, Xu C, Liu J, Li DM. Onsite bio-detoxification of steam-exploded corn stover for cellulosic ethanol production. Bioresource Technology, 2011. 102, 5123-5128.

[101] Lu YF, Wang YH, Xu GQ, Chu J, Zhuang YP, Zhang SL. Influence of high solid concentration on enzymatic hydrolysis and fermentation of steam-exploded corn stover biomass. Applied Biochemistry and Biotechnology, 2010. 160, 360-369. 
[102] Sassner P, Galbe M, Zacchi G. Techno-economic evaluation of bioethanol production from three different lignocellulosic materials. Biomass \& Bioenergy, 2008. 32, 422-430.

[103] Cao GL, Ximenes E, Nichols NN, Frazer SE, Kim D, Cotta MA, Ladisch M. Bioabatement with hemicellulase supplementation to reduce enzymatic hydrolysis inhibitors. Bioresource Technology, 2015. 190, 412-415.

[104] Buruiana CT, Vizireanu C, Garrote G, Parajo JC. Optimization of corn stover biorefinery for coproduction of oligomers and second generation bioethanol using non-isothermal autohydrolysis. Industrial Crops and Products, 2014. 54, 32-39.

[105] Li HQ, Jiang W, Jia JX, Xu J. pH pre-corrected liquid hot water pretreatment on corn stover with high hemicellulose recovery and low inhibitors formation. Bioresource Technology, 2014. 153, 292299.

[106] Li XZ, Lu J, Zhao J, Qu YB. Characteristics of corn stover pretreated with liquid hot water and fedbatch semi-simultaneous saccharification and fermentation for bioethanol production. Plos One, 2014. 9, 1-11.

[107] Lu J, Li XZ, Yang RF, Zhao J, Qu YB. Tween 40 pretreatment of unwashed water-insoluble solids of reed straw and corn stover pretreated with liquid hot water to obtain high concentrations of bioethanol. Biotechnology for Biofuels, 2013. 6, 159-169.

[108] Zeng MJ, Ximenes E, Ladisch MR, Mosier NS, Vermerris W, Huang CP, Sherman DM. Tissuespecific biomass recalcitrance in corn stover pretreated with liquid hot-water: Enzymatic hydrolysis (part 1). Biotechnology and Bioengineering, 2012. 109, 390-397.

[109] Xu J, Thomsen MH, Thomsen AB. Ethanol production from hydrothermal pretreated corn stover with a loop reactor. Biomass \& Bioenergy, 2010. 34, 334-339.

[110] Xu J, Thomsen MH, Thomsen AB. Pretreatment on corn stover with low concentration of formic acid. Journal of Microbiology and Biotechnology, 2009. 19, 845-850.

[111] Zeng MJ, Mosier NS, Huang CP, Sherman DM, Ladisch MR. Microscopic examination of changes of plant cell structure in corn stover due to hot water pretreatment and enzymatic hydrolysis. Biotechnology and Bioengineering, 2007. 97, 265-278.

[112] Nghiem NP, Senske GE, Kim TH. Pretreatment of corn stover by low moisture anhydrous ammonia (LMAA) in a pilot-scale reactor and bioconversion to fuel ethanol and industrial chemicals. Applied Biochemistry and Biotechnology, 2016. 179, 111-125.

[113] Sarks C, Bals BD, Wynn J, Teymouri F, Schwegmann S, Sanders K, Jin M, Balan V, Dale BE. Scaling up and benchmarking of ethanol production from pelletized pilot scale AFEX treated corn stover using Zymomonas mobilis 8b. Biofuels-UK, 2016. 7, 253-262.

[114] Sousa LD, Jin MJ, Chundawat SPS, Bokade V, Tang XY, Azarpira A, Lu FC, Avci U, Humpula J, Uppugundla N, Gunawan C, Pattathil S, Cheh AM, Kothari N, Kumar R, Ralph J, Hahn MG, Wyman CE, Singh S, Simmons BA, Dale BE, Balan V. Next-generation ammonia pretreatment enhances cellulosic biofuel production. Energy \& Environmental Science, 2016. 9, 1215-1223.

[115] Yoo CG, Kim H, Lu FC, Azarpira A, Pan XJ, Oh KK, Kim JS, Ralph J, Kim TH. Understanding the physicochemical characteristics and the improved enzymatic saccharification of corn stover pretreated with aqueous and gaseous ammonia. Bioenergy Research, 2016. 9, 67-76.

[116] Zhao C, Shao QJ, Ma ZQ, Li B, Zhao XJ. Physical and chemical characterizations of corn stalk resulting from hydrogen peroxide presoaking prior to ammonia fiber expansion pretreatment. Industrial Crops and Products, 2016. 83, 86-93.

[117] Zhao C, Ding WM, Chen F, Cheng C, Shao QJ. Effects of compositional changes of AFEX-treated and H-AFEX-treated corn stover on enzymatic digestibility. Bioresource Technology, 2014. 155, 34-40.

[118] Zhao C, Shao QJ, Li B, Ding WM. Comparison of hydrogen peroxide and ammonia pretreatment of corn stover: Solid recovery, composition changes, and enzymatic hydrolysis. Energy \& Fuels, 2014. 28, 6392-6397.

[119] Zhu JQ, Qin L, Li BZ, Yuan YJ. Simultaneous saccharification and co-fermentation of aqueous ammonia pretreated corn stover with an engineered Saccharomyces cerevisiae SyBE005. Bioresource Technology, 2014. 169, 9-18. 
[120] Jin MJ, Gunawan C, Balan V, Yu XR, Dale BE. Continuous SSCF of AFEX (TM) pretreated corn stover for enhanced ethanol productivity using commercial enzymes and Saccharomyces cerevisiae 424A (LNH-ST). Biotechnology and Bioengineering, 2013. 110, 1302-1311.

[121] Qin L, Liu ZH, Jin MJ, Li BZ, Yuan YJ. High temperature aqueous ammonia pretreatment and postwashing enhance the high solids enzymatic hydrolysis of corn stover. Bioresource Technology, 2013. 146, 504-511.

[122] Zhang C, Pang F, Li B, Xue SL, Kang Y. Recycled aqueous ammonia expansion (RAAE) pretreatment to improve enzymatic digestibility of corn stalks. Bioresource Technology, 2013. 138, 314-320.

[123] Bals BD, Teymouri F, Campbell T, Jin MJ, Dale BE. Low temperature and long residence time AFEX pretreatment of corn stover. Bioenergy Research, 2012. 5, 372-379.

[124] Jin MJ, Gunawan C, Balan V, Lau MW, Dale BE. Simultaneous saccharification and cofermentation (SSCF) of AFEX (TM) pretreated corn stover for ethanol production using commercial enzymes and Saccharomyces cerevisiae 424A(LNH-ST). Bioresource Technology, 2012. 110, 587 594.

[125] Jin MJ, Balan V, Gunawan C, Dale BE. Consolidated bioprocessing (CBP) performance of Clostridium phytofermentans on AFEX-treated corn stover for ethanol production. Biotechnology and Bioengineering, 2011. 108, 1290-1297.

[126] Li XA, Kim TH. Low-liquid pretreatment of corn stover with aqueous ammonia. Bioresource Technology, 2011. 102, 4779-4786.

[127] Yoo CG, Nghiem NP, Hicks KB, Kim TH. Pretreatment of corn stover using low-moisture anhydrous ammonia (LMAA) process. Bioresource Technology, 2011. 102, 10028-10034.

[128] Li X, Kim TH, Nghiem NP. Bioethanol production from corn stover using aqueous ammonia pretreatment and two-phase simultaneous saccharification and fermentation (TPSSF). Bioresource Technology, 2010. 101, 5910-5916.

[129] Lau MW, Dale BE. Cellulosic ethanol production from AFEX-treated corn stover using Saccharomyces cerevisiae 424A(LNH-ST). Proceedings of the National Academy of Sciences of the United States of America, 2009. 106, 1368-1373.

[130] Garcia-Torreiro M, Lopez-Abelairas M, Lu-Chau TA, Lema JM. Fungal pretreatment of agricultural residues for bioethanol production. Industrial Crops and Products, 2016. 89, 486-492.

[131] Saha BC, Qureshi N, Kennedy GJ, Cotta MA. Biological pretreatment of corn stover with white-rot fungus for improved enzymatic hydrolysis. International Biodeterioration \& Biodegradation, 2016. 109, 29-35.

[132] Song LL, Yu HB, Ma FY, Zhang XY. Biological pretreatment under non-sterile conditions for enzymatic hydrolysis of corn stover. Bioresources, 2013. 8, 3802-3816.

[133] Cui ZF, Wan CX, Shi J, Sykes RW, Li YB. Enzymatic digestibility of corn stover fractions in response to fungal pretreatment. Industrial \& Engineering Chemistry Research, 2012. 51, 71537159.

[134] Gao ZQ, Mori T, Kondo R. The pretreatment of corn stover with Gloeophyllum trabeum KU-41 for enzymatic hydrolysis. Biotechnology for Biofuels, 2012. 5, 28-38.

[135] Sun FH, Li J, Yuan YX, Yan ZY, Liu XF. Effect of biological pretreatment with Trametes hirsuta yj9 on enzymatic hydrolysis of corn stover. International Biodeterioration \& Biodegradation, 2011. 65, 931-938.

[136] Wan CX, Li YB. Effectiveness of microbial pretreatment by Ceriporiopsis subvermispora on different biomass feedstocks. Bioresource Technology, 2011. 102, 7507-7512.

[137] Wan CX, Li YB. Microbial delignification of corn stover by Ceriporiopsis subvermispora for improving cellulose digestibility. Enzyme and Microbial Technology, 2010. 47, 31-36.

[138] Wan CX, Li YL. Microbial pretreatment of corn stover with Ceriporiopsis subvermispora for enzymatic hydrolysis and ethanol production. Bioresource Technology, 2010. 101, 6398-6403.

[139] Xu CY, Ma FY, Zhang XY, Chen SL. Biological pretreatment of corn stover by Irpex lacteus for enzymatic hydrolysis. Journal of Agricultural and Food Chemistry, 2010. 58, 10893-10898. 
[140] Brodeur G, Telotte J, Stickel JJ, Ramakrishnan S. Two-stage dilute-acid and organic-solvent lignocellulosic pretreatment for enhanced bioprocessing. Bioresource Technology, 2016. 220, 621628.

[141] Cai LY, Ma YL, Ma XX, Lv JM. Improvement of enzymatic hydrolysis and ethanol production from corn stalk by alkali and N-methylmorpholine-N-oxide pretreatments. Bioresource Technology, 2016. 212, 42-46.

[142] Chen XW, Kuhn E, Jennings EW, Nelson R, Tao L, Zhang M, Tucker MP. DMR (deacetylation and mechanical refining) processing of corn stover achieves high monomeric sugar concentrations (230 $\left.\mathrm{g} \mathrm{L}^{-1}\right)$ during enzymatic hydrolysis and high ethanol concentrations $(>10 \% \mathrm{v} / \mathrm{v})$ during fermentation without hydrolysate purification or concentration. Energy \& Environmental Science, 2016. 9, 12371245.

[143] Jiang W, Xu J. A novel stepwise pretreatment on corn stalk by alkali deacetylation and liquid hot water for enhancing enzymatic hydrolysis and energy utilization efficiency. Bioresource Technology, 2016. 209, 115-124.

[144] Li WZ, Liu QY, Ma QZ, Zhang TW, Ma LL, Jameel H, Chang HM. A two-stage pretreatment process using dilute hydrochloric acid followed by Fenton oxidation to improve sugar recovery from corn stover. Bioresource Technology, 2016. 219, 753-756.

[145] Liu QY, Li WZ, Ma QZ, An SX, Li MH, Jameel H, Chang HM. Pretreatment of corn stover for sugar production using a two-stage dilute acid followed by wet-milling pretreatment process. Bioresource Technology, 2016. 211, 435-442.

[146] Lee JW, Kim JY, Jang HM, Lee MW, Park JM. Sequential dilute acid and alkali pretreatment of corn stover: Sugar recovery efficiency and structural characterization. Bioresource Technology, 2015. 182, 296-301.

[147] Buruiana CT, Vizireanu C, Garrote G, Parajo JC. Bioethanol production from hydrothermally pretreated and delignified corn stover by fed-batch simultaneous saccharification and fermentation. Energy \& Fuels, 2014. 28, 1158-1165.

[148] Mou HY, Li B, Fardim P. Pretreatment of corn stover with the modified hydrotropic method to enhance enzymatic hydrolysis. Energy \& Fuels, 2014. 28, 4288-4293.

[149] Zu S, Li WZ, Zhang MJ, Li ZH, Wang ZY, Jameel H, Chang HM. Pretreatment of corn stover for sugar production using dilute hydrochloric acid followed by lime. Bioresource Technology, 2014. 152, 364-370.

[150] Tan L, Tang YQ, Nishimura H, Takei S, Morimura S, Kida K. Efficient production of bioethanol from corn stover by pretreatment with a combination of sulfuric acid and sodium hydroxide. Preparative Biochemistry \& Biotechnology, 2013. 43, 682-695.

[151] Chen XW, Shekiro J, Elander R, Tucker M. Improved xylan hydrolysis of corn stover by deacetylation with high solids dilute acid pretreatment. Industrial \& Engineering Chemistry Research, 2012. 51, 70-76.

[152] Zimbardi F, Viola E, Nanna F, Larocca E, Cardinale M, Barisano D. Acid impregnation and steam explosion of corn stover in batch processes. Industrial Crops and Products, 2007. 26, 195-206.

[153] Bisinella V, Conradsen K, Christensen TH, Astrup TF. A global approach for sparse representation of uncertainty in Life Cycle Assessments of waste management systems. International Journal of Life Cycle Assessment, 2016. 21, 378-394.

[154] Clavreul J, Baumeister H, Christensen TH, Damgaard A. An environmental assessment system for environmental technologies. Environmental Modelling \& Software, 2014. 60, 18-30.

[155] Vadenbo C, Hellweg S, Astrup TF. Let's be clear(er) about substitution: A reporting framework to account for product displacement in life cycle assessment. Journal of Industrial Ecology, 2017. 21, 1078-1089.

[156] International Standards Organisation (ISO). ISO 14040, Environmental Management - Life Cycle Assessment - Principles and Framework. International Standards Organization 2006. Geneva, Switzerland. ISO 14040: 2006(E).

[157] IPCC Working Group I. Climate Change 2013: The Physical Science Basis. IPCC Working Group I Contribution to IPCC's Fifth Assessment Report. IPCC Working Group I Contribution to IPCC's Fifth Assessment Report. http://climatechange2013.org/; 2013. 
[158] Ecoinvent. Ecoinvent database. http://ecoinvent.com; 2016.

[159] Argonne National Laboratory. GREET model. https://greet.es.anl.gov/; 2017.

[160] Nielsen PH, Oxenboll KM, Wenzel H. Cradle-to-gate environmental assessment of enzyme products produced industrially in Denmark by Novozymes A/S. International Journal of Life Cycle Assessment, 2007. 12, 432-438.

[161] MacLean HL, Spatari S. The contribution of enzymes and process chemicals to the life cycle of ethanol. Environmental Research Letters, 2009. 4, 10.

[162] Dunn JB, Mueller S, Wang M, Han J. Energy consumption and greenhouse gas emissions from enzyme and yeast manufacture for corn and cellulosic ethanol production. Biotechnology Letters, 2012. 34, 2259-2263.

[163] US EPA. Draft regulatory impact analysis: Changes to renewable fuel standard program. Office of Transportation and Air Quality, Assessment and Standards Division. 2009. Washington, DC.

[164] Olofsson J, Barta Z, Borjesson P, Wallberg O. Integrating enzyme fermentation in lignocellulosic ethanol production: life-cycle assessment and techno-economic analysis. Biotechnology for Biofuels, 2017. 10, 14.

[165] Kioutsioukis I, Tarantola S, Saltelli A, Gatelli D. Uncertainty and global sensitivity analysis of road transport emission estimates. Atmospheric Environment, 2004. 38, 6609-6620. 


\section{Figure and Table Captions}

Fig. 1 System boundary for the biorefinery of corn stover to produce bioethanol.

Fig. 2 Global warming potentials of eight technological configurations for producing bioethanol from corn stover, based on individual datasets reported in the literature. (a) S1-Acid (27 cases), (b) S2-Alkaline (19 cases), (c) S3-Solvent-based (14 cases), (d) S4-Steam explosion (17 cases), (e) S5-Liquid hot water (11 cases), (f) S6-Ammonia-based (27 cases), (g) S7-Fungi (11 cases), (h) S8-Combi (15 cases) (Pies and blue numbers on top of the figures indicate the data completeness of each case; red underlined numbers on the top are the maximum values of the bars hitting the border; tables in (c), (g), and (h) list the out-of-range values of net GWP and net GWP without energy from residues).

Fig. 3 Global warming potentials of seven technological configurations for producing bioethanol from corn stover, based on Monte Carlo simulations. (a) S1-Acid, (b) S2-Alkaline, (c) S3-Solvent-based, (d) S4-Steam explosion, (e) S5-Liquid hot water, (f) S6-Ammonia-based, (g) S7-Fungi (E and M stand for expectation value and mode, respectively. Please note the X-axis of c) S3 is different from the others).

Fig. 4 Cumulative probability of the global warming potentials of Configurations S1-S7.

Fig. 5 Scenario uncertainty for global warming potentials with average American (USA) and Chinese (CHN) energy mixes compared to the default (DF) energy mix. (a) S1-Acid, (b) S2-Alkaline, (c) S4-Steam explosion, (d) S6-Ammonia-based, (e) S7-Fungi.

Table 1 Parameters used in modeling the eight process configurations for the bioconversion of corn stover into ethanol

Table 2 Ethanol production and net GWP values (average plus/minus standard deviation) for eight technological configurations per 1 tonne TS of corn stover, per 1 liter of bioethanol produced and per MJ of bioethanol produced

Table 3 Uncertainty contribution analysis of all parameters for all technological configurations (\%) (top four most important parameters in each configuration are underlined)

Table 4 Values of important parameters assigned to "best practice" compared with overall average values 